\title{
La construcción de etnoterritorios en las culturas indígenas de Oaxaca
}

\author{
Alicia M. Barabas
}

Este ensayo intenta una reflexión sobre las categorías espacio, lugar y territorio: espacio como continente más amplio, lugar como núcleo de densificación significativa y territorio como espacio cultural, instrumental e históricamente apropiado por una sociedad, que por lo común implica nociones de frontera. En este contexto pueden inscribirse las representaciones o nociones espaciales de origen mesoamericano presentes actualmente en los grupos etnolingüísticos de Oaxaca. En relación con esas representaciones, la autora intenta elaborar un modelo descriptivo de construcción de etnoterritorios que parte de la base de las nociones territoriales de centro y frontera, conectados éstos por redes, para delimitar etnoterritorios simbólicos construidos a partir de la cosmovisión, la mitología y las prácticas rituales.

A reflection on the categories of space, place and territory is addressed in this essay: space as a broader continent, place as a nucleus of meaningful density and territory as a cultural space, instrumentally and historically appropriate for a society, which usually implies notions of frontier. In this context the representations or spatial notions of Mesoamerican origin currently existing in the ethno-linguistic groups of Oaxaca can be registered. Regarding these representations, the author seeks to create a descriptive model to construct ethno-territories, which stems from the basis of territorial notions of center and frontier, connected by networks, in order to delimit symbolic ethno-territories constructed according to worldview, mythology and ritual practices.

ALICIA M. BARABAS: INAH-OaXaca. 
$\mathrm{L}$ a importancia de los estudios sobre territorialidad simbólica no sólo radica en el conocimiento etnológico que proporcionan sobre el sistema de representaciones espaciales de los pueblos indígenas, sino principalmente en que se constituyen como un cuerpo de datos para la delimitación de etnoterritorios, que sirve a los pueblos originarios como reactivación de la memoria y como instrumento para la reclamación de derechos territoriales dentro de los estados nacionales que los incluyen. En este sentido, existe jurisprudencia en América Latina y en otros países del mundo sobre la aceptación legal del "conocimiento local" para la delimitación de terriorios indígenas. ${ }^{1}$

En el ámbito de la etnología, la discusión sobre la persistencia de la cosmovisión y cuerpo de creencias de raíz mesoamericana en las culturas indígenas actuales ha sido retomada por casi todos los mesoamericanistas y estudiosos de las religiones indígenas, sin llegar a un acuerdo definitivo, aunque se reconozca que existen grandes "semejanzas parentales" entre las formas de representarse y usar el espacio de las culturas indígenas de ayer y de hoy. ${ }^{2}$ Estudios etnohistóricos y etnográficos concuerdan en que la cosmovisión de los pueblos indígenas concibe al universo, a la naturaleza, a la sociedad y al cuerpo humano como semejantes, y relacionados de acuerdo con el modelo normativo de la reciprocidad equilibrada.

En un trabajo reciente llamé ética del don al conjunto de concepciones, valores y estipulaciones que regulan las relaciones de reciprocidad equilibrada entre personas, familias, vecinos, autoridades, comunidades, en todos los campos de la vida social: el trabajo, el ciclo de vida, la fiesta, la política y lo sagrado (A. Barabas, 2003a). Se trata de una categoría básica que, en uno de sus aspectos, sustenta la relación con la naturaleza y sus entes sagrados basada en la concepción de que si se cumple con las

\footnotetext{
1 Tanto los pintupi de Australia (F. Myers, 1986) como los ye'kuanas de la Amazonía venezolana (N. Arvelo y K. Conn, 1995) se han valido del conocimiento y uso ritual de sus ancestrales lugares sagrados para promover la delimitación legal de sus territorios étnicos.

2 Entre muchos otros estudios pueden consultarse A. López Austin, 1984, 1989, 1990; J. Galinier, 1990; J. Glockner, 1996; B. Albores y J. Broda (coords), 1997; A. Medina, 2000; J. Broda y F. Báez-Jorge (coords.), 2001.
}

exigencias del don se obtiene bienestar y el equililbrio de la vida, si no es así, tal como muestran los mitos, se pierde la protección de lo sagrado y también la "suerte" y los dones, ya que las deidades se retiran llevándose los bienes y el territorio se vuelve árido, carente de vegetación y de agua. Mediante el don se establece una alianza entre las deidades y los humanos que permite la negociación sobre el territorio; por ello no es posible entender la interrelación humano-sagrado en las culturas indígenas sin considerar la ética humanizada y sociomorfizada que rige sus relaciones.

En otra ocasión (A. Barabas y M. Bartolomé, 1999: 24) llamamos religiones étnicas a las configuraciones religiosas que elaboran los grupos etnolinguísticos, ya que constituyen totalidades que no pueden ser seccionadas de acuerdo con las procedencias de los elementos culturales que las integran, en la medida que éstos han sido apropiados y reelaborados por los actores sociales. Aun así, son evidentes tanto la impronta del catolicismo como la matriz y las raíces culturales mesoamericanas en la representación del espacio y la construcción de la territorialidad en las culturas indias actuales. Los ancestros, los dueños de lugar, los naguales, los santos y vírgenes, son parte de esas nuevas configuraciones religiosas, que los incluyen muchas veces sin amalgamarlos.

Las representaciones sobre el espacio y las pautas culturales de construcción de la territorialidad son unas de las categorías profundas, de larga duración y transformación sutil, que persisten más allá de otros cambios sociales y culturales. Por ello en el presente siguen siendo de importancia capital las cuatro orientaciones cardinales y el centro como estructuradores del universo cósmico, de la naturaleza, del mundo social y del cuerpo humano. Los lugares geográficos son —o están habitados— por entidades territoriales con gran capacidad de acción, ante las cuales las personas deben realizar cuidadosos rituales y ofrendas para aplacar enojos y propiciar permisos y ayudas de lo sagrado que redundarán en abundancia y salud.

Estas consideraciones y preocupaciones me llevaron a plantear como objeto de estudio las formas simbólicas en que los pueblos indios actuales construyen territorialidad a través de la puesta en acción de lugares sagrados, rituales, procesiones y discursos míticos. Dada la amplitud y 


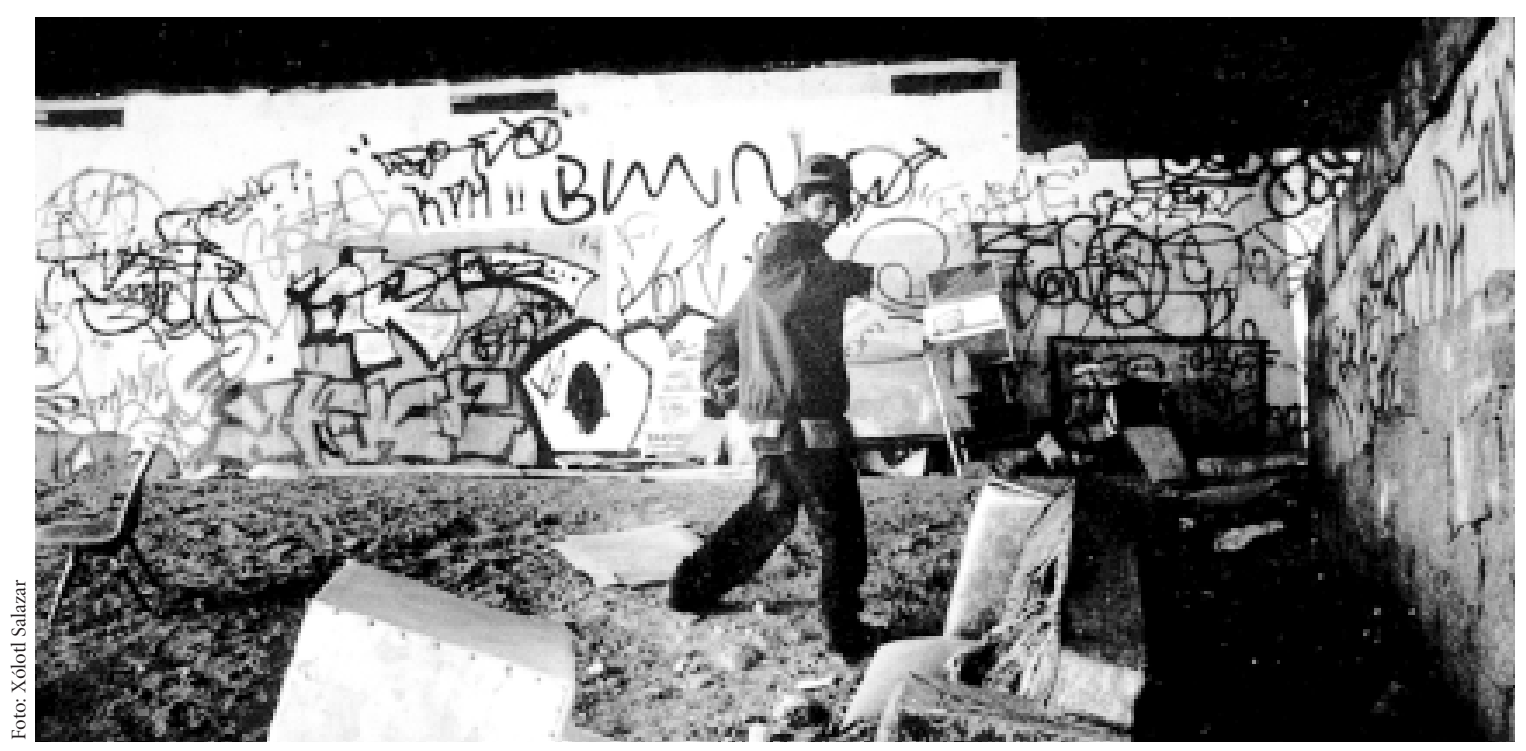

Observatorio y Periférico; México, D.F., 1999.

complejidad del universo de estudio este ensayo intentará organizar un modelo de representación del espacio de las culturas indígenas de Oaxaca, para el análisis de los procesos de construcción-apropiación territorial que protagonizan y que conducen a la formación de etnoterritorios.

\section{TERRITORIALIDAD SIMBÓLICA. LOS ETNOTERRITORIOS}

¿Por qué territorialidad simbólica?3 En cierta forma para alejarnos de las categorías externas, constituidas y reificadas por el Estado, como son las geográficas, agrarias, político-administrativas (municipales) y otras; y porque las simbólicas parecen ser representaciones territoriales estructuradas en acuerdo con la cosmovisión o lógica interna propia de las culturas.

\footnotetext{
${ }^{3}$ El desarrollo conceptual y los apoyos etnográficos a las argumentaciones que se presentan sintéticamente en este texto están contenidos en mi ensayo "Etnoterritorialidad sagrada en Oaxaca", incluido en el volumen I del libro Diálogos con el territorio. Simbolizaciones sobre el espacio en las culturas indígenas de México, del que soy coordinadora y que se encuentra en proceso de publicación por el INAH.
}

La territorialidad ha sido estudiada por la geografía humana, la geografía del paisaje, el medioambientalismo, la historia de las religiones, entre otras especialidades. Esta última y la etnología, después de las aportaciones claves de M. Eliade (1967), R. Otto (1965), M. Leenhardt, (1961), entre otros, sobre lo que podríamos llamar espacios sagrados, se habían alejado de la temática. Recientemente se ha reabordado desde la fenomenología y otras variadas perspectivas analíticas, ${ }^{4}$ lo que ha venido a complejizar y enriquecer la interpretación de los territorios como sistemas de símbolos, cuya existencia simbólica tiene tanto peso como su existencia fáctica, ya que puede servir de fundamento para determinar linderos y fronteras, cuando éstos han sido históricamente alterados pero conservados en la memoria colectiva y en el uso ritual.

He preferido el uso del concepto "territorio" más que el de "paisaje", consciente de las diferencias, aunque sutiles, entre ambos. E. Hirsch (1995) señala que en la concepción europea de la naturaleza como paisaje pueden

\footnotetext{
${ }_{4}^{4}$ Pueden consultarse: G. Ericksen, 1980; E. Soja, 1985; F. Myers, 1986; D. Smith, 1990; A. Aveni, 1991; M. Rodman, 1992; A. Gupta y Ferguson, 1992; E. Hirsch y M. O'Hanlon, 1995; S. Schama, 1995; S. Feld y K. Basso, 1996; E. Casey, 1996; M. J. Jolivet y P. Léna, 2000.
} 


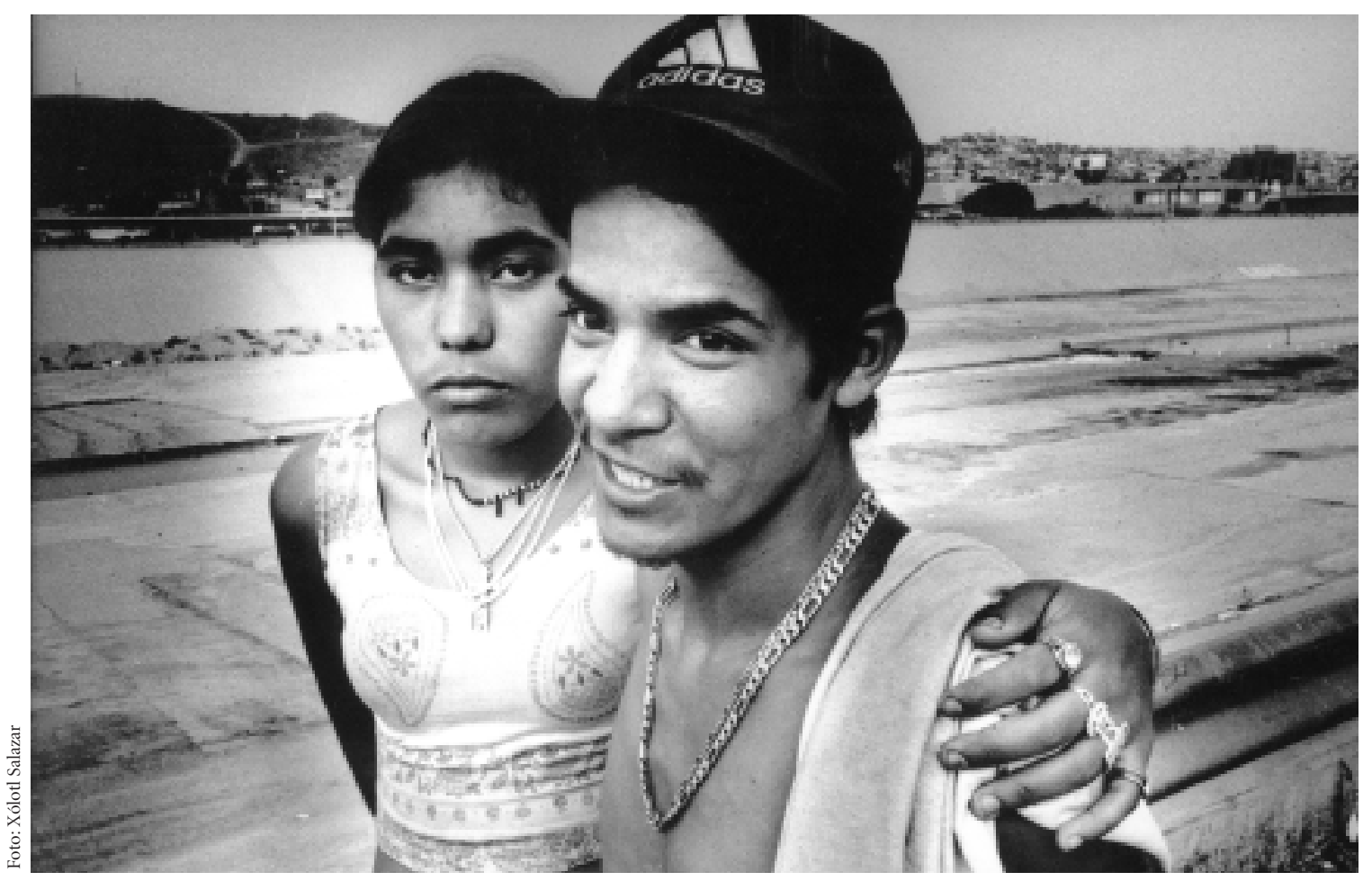

La Morena y el Chonte; El Bordo, Tijuana, 2000.

identificarse distintas modalidades derivadas de analogías sociomorfas. En el medioevo la naturaleza era parte de la creación divina, en tanto que en los siglos XVII y XVIII la idea sobre ella se seculariza, pero se convierte en un escenario que sirve de vehículo a expresiones de una realidad espiritual e interior que privilegia la estética, tal como se aprecia en la pintura, la narrativa y la poesía bucólicas. En el racionalista siglo XIX el ser humano se adueña de la naturaleza con el afán de modificarla y el paisaje se vuelve objeto de estudio y representación geométrica, lo que se traduce en documentos cartográficos y en diversas clasificaciones y mediciones. Entre los primeros intentos por comprender el paisaje más allá de la naturaleza, como una creación cultural, se encuentra el de Sauer en la década de 1960 (E. Hirsch, op. cit:: 9), quien polemizaba con los deterministas ambientales.

Los estudiosos de la geografía humana —en particular los geógrafos franceses y alemanes, y los de orientación fenomenológica - suelen privilegiar hoy en día el concepto de paisaje por sobre el de espacio o territorio, adjudicándole a aquél un carácter concreto, perceptual, vivencial y próximo que evidencia la relación humana afectiva con el espacio. El paisaje es señalado como típico de un área y del pueblo que la habita, e igualmente los habitantes se identifican y son identificados con ciertos paisajes como emblemas de su tierra y su identidad. El paisaje es considerado como símbolo del "terruño" y, tal como señala G. Giménez (2001), se convierte en metonimia y emblema del territorio.

Por otra parte, paisaje parece tener connotaciones más estéticas y menos políticas que territorio. Éste resulta ser un término con contenidos geopolíticos, que da por entendida la centralidad de la cuestión de los derechos territoriales de los pueblos indígenas. La naturaleza o el espacio pueden ser concebidos sin límites, pero los territorios habitados y apropiados sí los tienen, tal como dejan ver los códices, mapas, lienzos y títulos, así como también la ritualidad y la narrativa. 
El espacio es una categoría diversamente conceptualizada por las ciencias sociales contemporáneas. Algunos especialistas lo consideran como una suerte de contenedor neutral en el que se inscriben concepciones, creencias, prácticas culturales y memoria histórica (A. Gupta y J. Ferguson, 1992: 7). Otros, como materia prima o realidad material preexistente (G. Giménez, 1999: 27) que tiene un valor de uso pero no está moldeado por el hombre. Para otros más, de orientación fenomenológica (E. Casey, 1996), el espacio tiene un sustrato de significaciones preexistentes, dado por la excepcionalidad de los fenómenos geográficos, que son aprehendidos por la sociedad y pasan a integrar simbolizaciones posteriores. En este caso, el espacio es concebido como otro actor partícipe en la construcción de significados culturales.

Desde mi perspectiva, el espacio no es inerte sino un principio activo en la construcción del territorio, por lo que podría pensarse en procesos interactivos entre los usuarios y espacios específicos. Dicho de otro modo, los espacios particulares reciben cargas sociales de significación y las reflejan hacia la sociedad sugiriéndole una multiplicidad de símbolos, discursos y prácticas rituales. Espacio lo entiendo como el ámbito en el que se inscriben tradiciones, costumbres, memoria histórica, rituales y formas muy diversas de organización social, que lo van constituyendo como territorio cultural; un espacio nombrado y tejido con representaciones, concepciones y creencias de profundo contenido emocional. Por ello, un dato significativo en el estudio de la territorialidad es la toponimia propia, que puede aludir a concepciones cosmológicas, a características del medio o a hechos remarcables ocurridos en el lugar.

El territorio es utilizado tanto por la geografía cultural y por la antropología como un concepto que reúne al espacio con el colectivo, y ha sido entendido como la parte del espacio que una colectividad considera como propio (J. M. Valvuende, 1999: 218). Desde mi perspectiva se refiere a los espacios geográficos culturalmente modelados, pero no sólo los inmediatos a la percepción (paisaje) sino también los de mayor amplitud, que son reconocidos en términos de límites y fronteras. La noción de territorio como un espacio propio bordeado de fronteras, por porosas que éstas puedan ser, a veces no existe en el nivel supracomunitario o étnico; en varios grupos las nociones etnoterritoriales han quedado confinadas a los espacios comunitarios.

El territorio puede ser definido como espacio culturalmente construido, lo que implica que es valorizado y apropiado simbólica e instrumentalmente por la sociedad $(\mathrm{Cl}$. Raffestin, 1980: 129), y como espacio socializado (J. Escalera, 1999). Giménez (1999: 27) apunta que es el espacio de inscripción de la cultura, pero advierte asimismo que se trata de un valor de cambio que implica relaciones de poder y negociaciones de significado. También Gupta y Ferguson (1992: 11) señalaban que los significados que se crean sobre los lugares del territorio cultural se negocian entre los actores o, más áun, diríamos que la conciliación de significados sobre lugares se establece mediante la articulación de los diversos discursos sociales y prácticas colectivas. De estas apreciaciones resulta que el territorio es factor de disputa y de relaciones de poder entre grupos, no sólo en términos de recursos escasos y preciados por los que se compite sino también como construcción simbólica, en la que el poder y la negociación se ejercen también en las relaciones con lo sagrado.

El proceso de apropiación del espacio, que lo convierte en territorio, puede ser de carácter tendencialmente instrumental o simbólico aunque ambos suelen combinarse en las sociedades concretas. Cuando predomina - $\mathrm{O}$ escogemos para el análisis - una aproximación simbólica es fundamental considerar los componentes valorativos, culturales y afectivos colectivos, aunque no debe perderse de vista que a través de la apropiación simbólica el territorio resulta también internamente heterogéneo, estratificado y diversamente cualificado. Convenimos entonces con Giménez (2001) cuando dice que el territorio es una realidad multisignificativa que, precisamente por la condensación de significados, puede ser definida como "geosímbolo"; símbolo metonímico de la identidad de una comunidad, un grupo étnico, una región o un país. Tal vez sea oportuno destacar que, más allá de las diferencias de enfoque, la mayoría de los actuales estudiosos del tema coincide en conceptualizar el territorio como un sistema de símbolos, una manera de clasificar, cualificar y habitar el espacio, que sigue pautas y crea códigos transmisibles culturalmente. La territorialidad hace entonces referencia al 
proceso histórico de articulación entre naturaleza y sociedad en específicos contextos de interacción.

Es por todos reconocido que los pueblos indígenas perciben y valoran la tierra y el territorio como espacios sagrados, aun cuando paralelamente tienen otras valoraciones seculares. En este ensayo se ha privilegiado la apropiación sacralizada del etnoterritorio, lo que no quiere decir que éste no pueda ser definido y delimitado a través de otras categorías ajenas a lo sagrado, ni que todas las vivencias de los actores individuales y sociales en el territorio sean sacralizadas. ${ }^{5}$

Los territorios culturales o simbólicos que habitan los grupos etnolingüísticos pueden ser llamados etnoterritorios y ser entendidos como el territorio histórico, cultural e identitario que cada grupo reconoce como propio, ya que en él no sólo encuentra habitación, sustento y reproducción como grupo sino también oportunidad de reproducir cultura y prácticas sociales a través del tiempo. El etnoterritorio remite al origen y a la filiación del grupo en el lugar, y los niveles de autorreconocimiento pueden ser étnicos, regionales, subregionales o comunales.

La etnoterritorialidad es un fenómeno colectivo que resulta de la histórica y múltiple articulación establecida entre la sociedad y su medio ambiente, tanto en la dimensión local (comunitaria), que es la más frecuentemente reconocida, como en la global (étnica) que supone niveles de abstracción, ya que no se trata de territorios de lo cotidiano sino de ámbitos espaciales más amplios que los comunitarios. En mi apreciación los etnoterritorios pueden comenzar a entenderse a partir de la singular conjunción de las categorías de tiempo, espacio y sociedad que se concretan en la historia de un pueblo en un lugar.

Una categoría principal en la construcción nativa de la etnoterritorialidad es entonces la que reúne tiempo y espacio, historia en el lugar, que resulta ser el soporte central del proceso de identificación y de la cultura porque integra concepciones, creencias y prácticas que vinculan

\footnotetext{
${ }^{5}$ Los aspectos geográficos, medioambientales, económicos y políticos involucrados en el estudio del territorio, sus recursos y formas de posesión o tenencia no serán tratados como temas de estudio en esta ocasión, aunque ciertamente están implicados en la construcción simbólica del territorio.
}

a los actores con los antepasados y con el territorio que éstos les legaron (A. Barabas, 1997). El etnoterritorio, que estoy entendiendo sintéticamente como la concreción de la historia en el lugar, es el territorio culturalmente construido por un grupo etnolingüístico a lo largo del tiempo. ${ }^{6}$

Al pensar el territorio como culturalmente construido y apropiado, debe reconocerse al lugar como una noción fundamental. El lugar es una categoría privilegiada por los fenomenólogos estudiosos de la territorialidad porque se circunscribe al ámbito de la vivencia individual e interpersonal, ajenas a la abstracción conceptual. Algunos de sus defensores dicen que el lugar sintetiza el encuentro entre tiempo y espacio (Casey, 1996: 36), otros que el espacio, al semantizarse, se construye socialmente como $\operatorname{lugar}^{7}$ (A. Gupta y J. Ferguson, 1992: 11). Debemos convenir en que para los actores sociales indígenas no hay territorios abstractos sino aquellos marcados por lugares poderosos, tatuados por las gestas de los héroes míticos y los rituales que los cargan de significados sagrados.

Es preciso agregar que los lugares sagrados que constituyen el territorio cultural pueden tener unidades interiores de significado que son las marcas o huellas; sitios cargados de potencia del numen por contacto ( $v . g$. huellas de los pies, del caballo, del malacate, la huella sinuosa de la culebra). Los lugares y las marcas están asociados a eventos míticos y rituales: en ellos viven, o ellos son, y allí se manifiestan las potentes entidades territoriales, con voluntad y figura, ${ }^{8}$ conocidas como dueños del lugar, que viajan de sitio en sitio y van estableciendo lugares y marcas emblemáticos del etnoterritorio, traídos desde la memoria a las narraciones y prácticas rituales contemporáneas.

Desde una aproximación émica, la percepción y apropiación de un lugar es previa a cualquier representación

\footnotetext{
${ }^{6}$ Si bien esta investigación no ha tenido como propósito rastrear la construcción histórica de la región, ni de las unidades sociopolíticas prehispánicas o las coloniales, el anclaje en la historia es central en los procesos de construcción etnoterritorial.

${ }^{7}$ En este aspecto aluden a la polémica que sostienen estos autores, entre otros, sobre la prioridad de la construcción del concepto territorial o la prioridad de la vivencia del lugar.

${ }^{8}$ Dentro de la conceptualización de M. Eliade (1967: 19) los dueños de lugar son hierofanías, es decir, manifestaciones o revelaciones de lo sagrado, que tienen por efecto destacar un lugar del medio circundante y hacerlo cualitativamente diferente.
} 


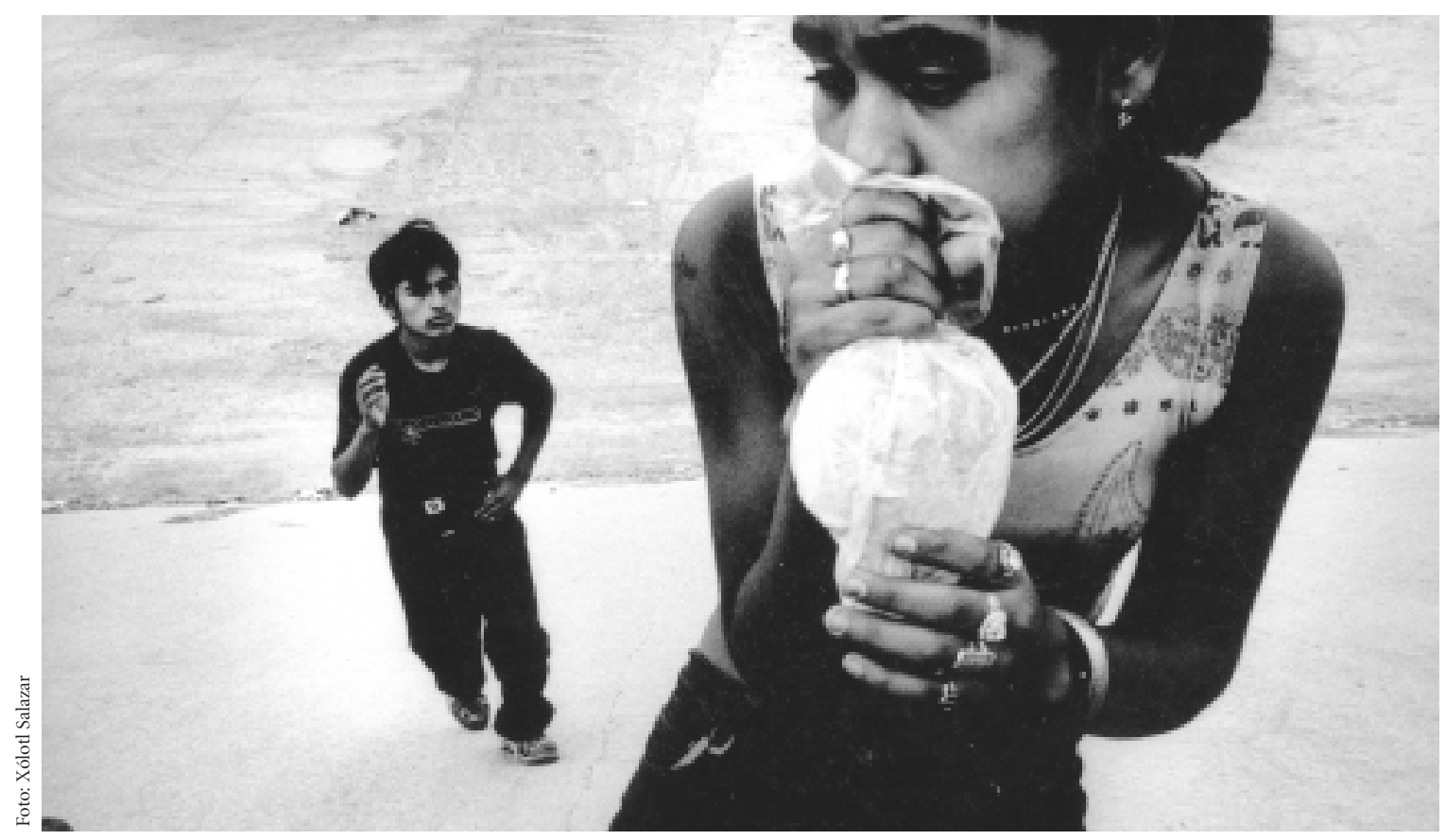

La Morena; El Bordo, Tijuana, 2000.

global del espacio. Para una explicación ética, en cambio, un lugar sagrado no lo es por los númenes que allí moran o irrumpen sino porque forma parte de una representación ordenada del espacio que constituye un sistema de significados plasmados en símbolos. Me parece importante señalar que la noción de sistema de símbolos territorial, en tanto relación ordenada entre partes, en el cual el significado está dado por la posición de cada parte en el conjunto, no resulta contradictoria ni excluyente con la noción fenomenológica de lugar, como punto de densificación significativa, toda vez que el "lugar vivido" se organiza en un campo de significación diferente al del "lugar posicional" que busca el analista que construye el sistema. Por otra parte, los actores sociales que viven un lugar como numinoso e hierofánico, lo conciben como sagrado porque responde a unas representaciones culturales, inconscientes pero reguladoras, que orientan la configuración del territorio cultural. Dicho de otro modo, la irrupción de lo sagrado en el lugar responde al modelo marcado por la representación cultural del espacio. El concepto fenomenológico de lugar no se contradice con el sistémico, ya que la irrupción de lo sagrado sigue el modelo marcado por la representación cultural del espacio. La simbolización de territorios, lugares y marcas sagrados se fundamenta en el sistema de representación del espacio y en las concepciones sobre el cosmos, ya que éstos configuran códigos que se ponen en acción al simbolizar el territorio.

A partir de los datos etnográficos se puede señalar que los lugares y los entes del lugar no son concebidos como poseedores de cualidades unívocas ni preestablecidas, sino de potencialidades duales (bien-mal) que dependen de cada particular encuentro con los humanos. Así como no existe una ofrenda que sirva para todo tipo de rito o situación, sino que la composición de cada una depende del contexto social y de la voluntad expresa de la entidad sagrada, tampoco existe un proceder fijo de los dueños para toda circunstancia, sino que éste depende del contexto y de las condiciones de cada interacción. Es la experiencia concreta de lo sagrado vivida en el lugar, y la representación del cosmos transmitida como sustrato en los mitos, rituales y otras prácticas sociales, lo que crea ese 


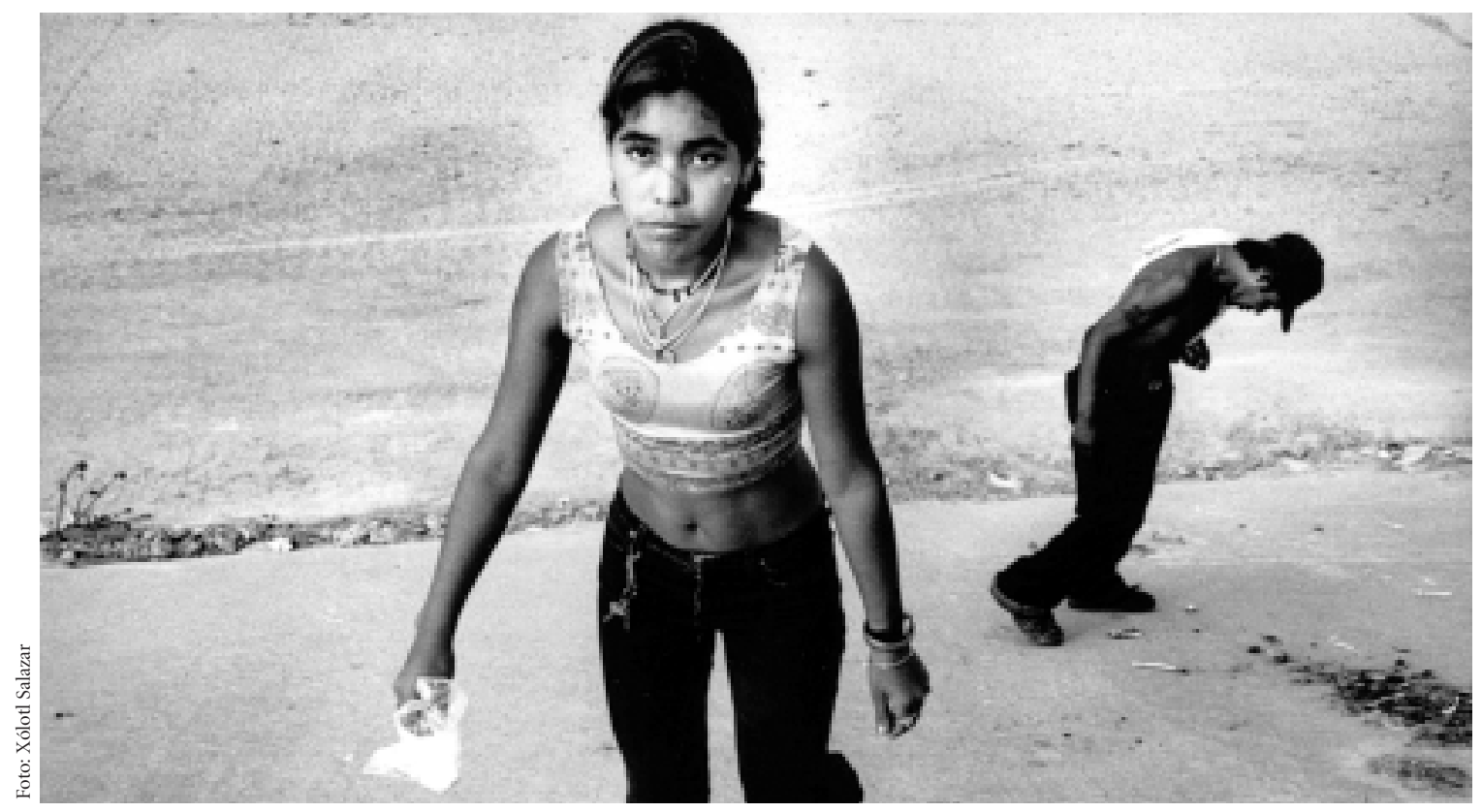

La Morena; El Bordo, Tijuana, 2000.

campo de significado concretizado en el lugar. ${ }^{9}$ Si bien entonces el modelo de representación del espacio es el que determina los lugares sagrados y las relaciones entre ellos en un sistema, los lugares de un territorio resultan también de sus mitos y ritos, que los urden, los bordan y los habitan. Los mitos y los ritos construyen los lugares sagrados con las cualidades que los caracterizan (son pesados, delicados, encantados, de respeto), y también con las figuras de las entidades que viven en ellos con sus atributos, fisonomía, carácter y hazañas.

Los lugares emblemáticos y sus marcas son elementos geográficos que funcionan, siguiendo a Giménez (1999: 42), como monumentos y resúmenes metonímicos, por lo

\footnotetext{
${ }^{9}$ Acerca de la especificidad de cada lugar, son claras las palabras de un médico tradicional de la Sierra Norte zapoteca: “...lo que sucede depende de los dueños de cada lugar; nosotros tenemos que hablar con ellos, bonito, para que el dueño nos hable en el sueño y nos diga qué es lo que quiere, y entonces nosotros tenemos que cumplirle y darle lo que nos está pidiendo y el dirá si le gustó, si lo recibe. Todo es de acuerdo con cada lugar, hay lugares donde corre agua, húmedos, con mucho aire, o calor; y entonces la curación será diferente de acuerdo con el lugar."
}

que se convierten en centros mnemónicos de cada cultura. La gente desarrolla imágenes cognitivas o mapas mentales (W. Douglass, 1999: 18) de los lugares y la relación entre ellos traza redes y construye fronteras territoriales. Respecto con los lugares y los eventos significativos allí ocurridos se clasifica el territorio y se organiza la geografía natural como un código de señales que sirve para recordar. De allí que, como propone F. Myers (1986: 59), el mito de las hazañas del héroe en el lugar legitima la posesión histórica y actual del mismo.

Tanto los territorios locales como los globales tienen puntos geográfico-simbólicos especialmente significativos para los usuarios. Estos puntos referenciales habitados por los dueños del lugar, que son objeto de variados discursos y rituales, son considerados emblemáticos y pueden ser identificados como lugares sagrados: centros o puntos de densificación significativa, a partir de los cuales se establecen fronteras comunales, subregionales y étnicas. La mayoría de los lugares sagrados persisten a través del tiempo y llegan a constituirse en emblemas territoriales e identitarios. Los lugares, y las marcas en ellos, son percibidos y vividos como únicos y ajenos a cualquier repre- 
sentación global del espacio, aunque responden a esa representación. La etnografía contemporánea nos muestra que, en gran medida, ese código basal de representación y concepción del espacio deviene del mesoamericano, si bien profunda y polifónicamente transformado.

\section{UN MODELO PARA LA REPRESENTACIÓN DEL TERRITORIO}

Estudios comparativos permiten aseverar que en numerosas culturas las orientaciones generales se organizan en dimensiones horizontales y verticales, y que éstas se reflejan en las cosmologías y en la configuración del espacio humano (I. Altman y M. Chemers, 1980: 32). La dimensión vertical con frecuencia genera la concepción de espacio tridimensional dividido en planos: arriba, medio y abajo, muchas veces comunicados entre sí a través del centro; y la dimensión horizontal, por lo común representada como cuadrángulo, rectángulo o romboide, pero también como círculo, organiza las orientaciones: centro y frontera (periferia, límite). La concepción de centro, que intersecta el espacio de arriba y de abajo y desde donde se marcan fronteras, suele construirse como lugar sagrado, sea montaña o templo, a partir del cual se marcan las otras direcciones. Convertidas las dimensiones espaciales en orientaciones cardinales contaríamos: norte, sur, este, oeste, centro, zenith y nadir.

Retomando estas consideraciones generales para las culturas de Oaxaca, observamos que el modelo de representación del espacio en dimensiones verticales y horizontales nos permite entender la dinámica de construcción-apropiación de los territorios locales y globales, así como del territorio de la comunidad o espacio humanizado, y el del monte o espacio salvaje, que pertenece a los dueños. De acuerdo con la dimensión horizontal se puede decir que todo lugar sagrado es concebido como un centro, a partir del cual se marcan las fronteras y se generan umbrales, esto es, transiciones entre espacios de diferente cualidad, atributos y valoración que median la entrada y la salida de lugares. Para atravesar estos umbrales se requiere de ritos de purificación (abluciones y abstinencias) y protectivos (de acceso y salida), que implican comportamientos determinados. Centros y fronteras están conectados por redes, que pueden ser caminos, migraciones fundadoras, rutas de peregrinaciones hacia santuarios, o el camino de los muertos en el inframundo. En cuanto a la dimensión vertical, es importante recalcar que en las culturas de raíz mesoamericana los tres planos interconectados por el centro están a su vez integrados por diferentes pisos o niveles.

Los tipos de lugares sagrados identificados, así como los mitos y rituales más significativos en la construcción de territorios simbólicos locales (comunitarios) y globales (etnoterritorios), permiten elaborar un modelo de territorialidad sustentado en las dimensiones vertical y horizontal y en las nociones de centro, frontera, umbral y redes. Este modelo de representación del espacio hace posible leer los etnoterritrorios como un conjunto de centros, a los que se tiene acceso mediante umbrales, que permiten marcar las fronteras del territorio propio con el de otros grupos y trazar los ejes o caminos simbólicos que conectan los centros con las fronteras conformando redes. ${ }^{10}$ Para dar sólo un ejemplo, que se repite en la Mixteca y en otras regiones, en el etnoterritorio del grupo etnolingüístico mazateco se identifican tres lugares sagrados o centros emblemáticos de cada una de las subregiones, a partir de los cuales se reconocen las orientaciones cardinales y los cerros que marcan los límites más amplios: el cerro Rabón en la subregión Baja, el cerro San Martín Caballero en la Media y el cerro de la Adoración o Chikón Tokosho en la Alta, éste último emblemático de toda la mazateca.

La concepción del espacio-cosmos en los pueblos indígenas actuales sigue siendo cuatripartita, dividida en cuatro orientaciones cardinales (E-O-N-S) que comportan vientos, colores $\mathrm{y}$ augurios, $\mathrm{y}$ un centro por donde pasa la columna universal o axis mundi (árbol, cuerda, escala, cruz) que conecta las tres dimensiones: supramundo, superficie e inframundo. La tierra es concebida como una isla o una superficie flotando sobre agua subterránea. La entidad dueña del agua de manantial suele ser femenina (culebra, sirena, virgen, etc.). En el agua dulce con fre-

\footnotetext{
${ }^{10}$ En este trabajo sólo trataré los centros y las fronteras y en mínima medida los umbrales y las redes, que han sido extensamente presentados en mi ensayo de 1993c.
} 
cuencia mora la serpiente cornuda, la más grande de las cuales vive en el mar. Las cuevas son representadas como entradas y salidas de túneles que, trazando una suerte de mapa hormiguero, surcan las entrañas de la tierra comunicando ese plano del universo. En las cuatro esquinas se encuentran los sostenes del mundo: númenes representados como vientos, árboles, columnas, cerros, ancestros, dueños de lugar. En la dimensión vertical el espacio se articula en función de las alturas, concebidas como sitios de poder, desde donde "se abarca todo hasta el horizonte". La montaña, los templos en su cima y los edificios que la proyectan son los símbolos principales de ese poder y pueden entenderse como centro del mundo y axis mundi.

Como ya mencioné, la cardinalidad es una de las categorías nodales en la estructuración del espacio y de la ubicación de las personas en él. Hacia las cuatro esquinas del mundo (puntos cardinales), desde el centro, se dirige toda plegaria y acción ritual, por igual en el espacio del monte, el pueblo y la casa, para todo pedido de permiso y todo "pago" (ofrenda y sacrificio) por lo solicicuatro esquinas cardinales, los cuatros dueños, los cuatro vientos. ${ }^{11}$ El centro, lugar del corazón del pueblo, es concebido como el lugar más sagrado porque es el punto de contacto entre cielo, tierra e inframundo, pero también el más peligroso ya que en él pueden cruzarse los vientos, en ocasiones representados como un remolino. Los lugares sagrados emblemáticos de cada comunidad y de los grupos etnolingüísticos reproducen este modelo y se orientan hacia los cuatro puntos cardinales.

El acercamiento a la territorialidad simbólica sagrada de los indígenas contemporáneos se ha realizado a través

\footnotetext{
${ }^{11}$ En los rituales mazatecos de curación el chjota chiné nombra los cuatro puntos cardinales, los cuatro dueños, los cuatro cerros y cuevas, los cuatro santos de los alrededores, ya que las enfermedades son causadas por los dueños ofendidos por el mal uso de sus lugares. Durante un ritual agrícola mixe, el xemabie coloca "tres cigarros encendidos en el suelo, como una ofrenda a los tres aná ( $p o: b$ aná, trueno blanco; caps aná, trueno rojo y pu:c aná, trueno negro...). El pescuezo del ave se coloca sobre los sacos de la semilla de maíz que será sembrada y se le sacrifica con las siguientes palabras: ... agradezco a los cuatro vientos, el viento verde (norte), el viento gris (sur)..." (Lipp, 1983: 90 y 91).
}

de la cosmovisión, específicamente desde la mitología, de la que han resultado particularmente importantes los mitos fundacionales, los cosmogónicos y los etiológicos, porque delimitan y organizan el mundo natural y social. Un tipo particular de mitología que encontramos entre los grupos de Oaxaca es el que hemos llamado de privación (M. Bartolomé y A. Barabas, 1996), ya que alude a la pérdida de riquezas y recursos y al deterioro ambiental del territorio debidos al abandono de los númenes, en beneficio de otros grupos indígenas o de los no indios. Otro tipo, también muy frecuente en Oaxaca de ayer y de hoy son los mitos aparicionistas de los ejemplares católicos: vírgenes y santos aparecidos que se hacen santos patronos de los pueblos que fundan y cuyo territorio y poblado protegen, desempeñando un papel fundador que antes cumplían —y aún cumplen— los ancestros y las deidades tutelares (A. Barabas, 1991, 1997).

La territorialidad simbólica también, y principalmente, puede ser leída a través de los diferentes procesos rituales y ceremoniales que alternan la vida cotidiana de las comunidades. Los rituales ${ }^{12}$ relacionados directamente con la territorialidad, sean privados o públicos y dirigidos o no por un especialista religioso, son los del ciclo vital, los propiciatorios, los adivinatorios y los conmemorativos. Un quinto tipo incluye los rituales de umbral. Los rituales del ciclo vital que se relacionan con los cerros, las cuevas y los manantiales son principalmente los de nacimiento, fortalecimiento y muerte. Entre los propiciatorios se encuentran los de pedimento, que buscan obtener lluvia, cosecha, ganado, salud, fertilidad, suerte, buen desempeño como autoridad, conocimiento chamánico, buen camino de migración, protección, dinero y bienes materiales. Otros ritos propiciatorios son terapéuticos porque propician la recuperación de la salud (del ánima o tona) y de daño (pedido de enfermedad). Los adivinatorios pronostican el clima del año, la calidad e intensidad de las lluvias, permiten obtener diagnósticos de enfermedades y terapeúticas, y hacer augurios personales o

\footnotetext{
12 Se trata de una clasificación operativa que incluye los rituales relacionados con la territorialidad, lo que de ningún modo agota la gama de procesos rituales que se llevan a cabo en las comunidades indígenas (A. Barabas, 2003b).
} 


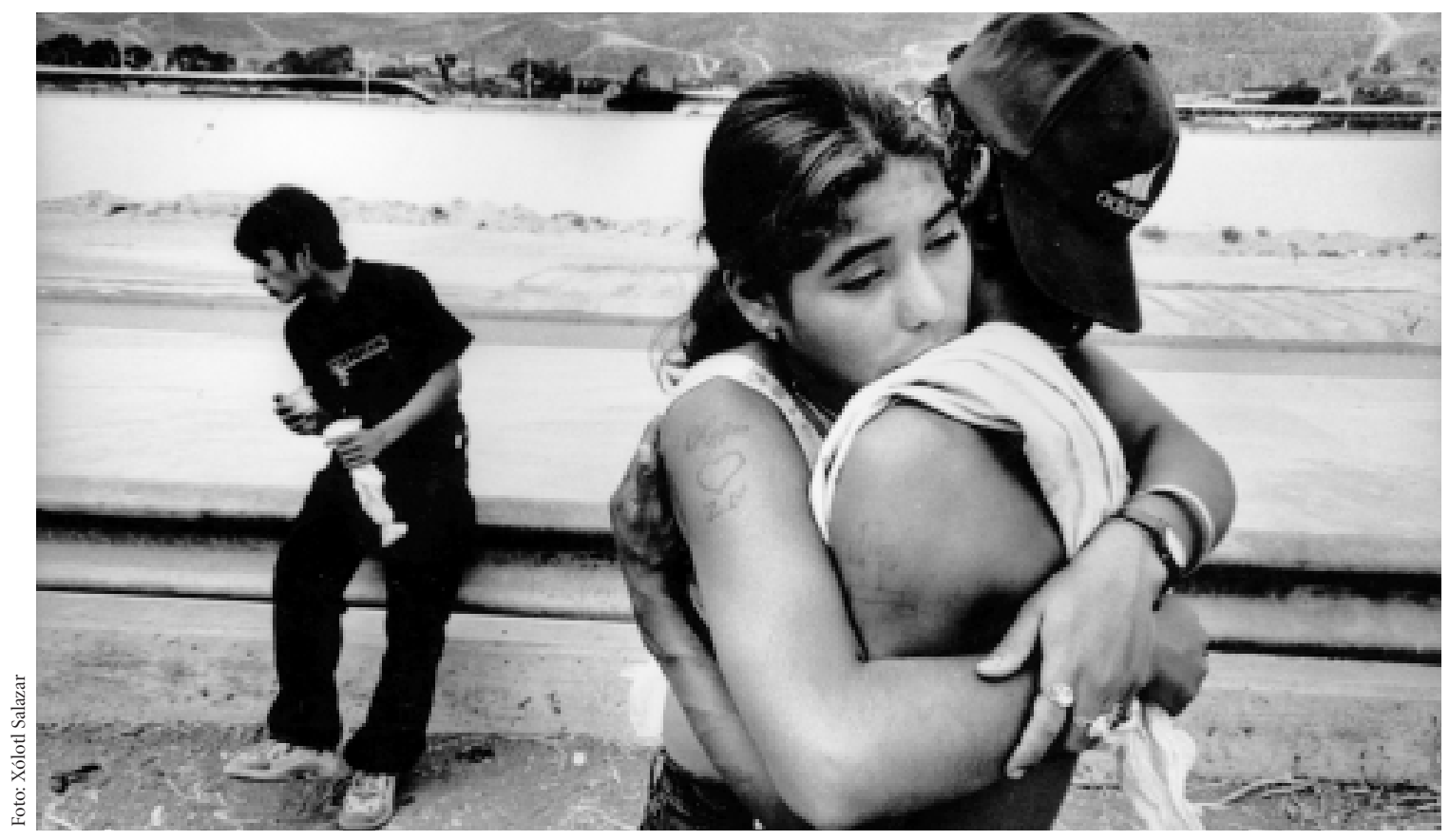

La Morena; El Bordo, Tijuana, 2000.

comunitarios; muchas veces son las autoridades municipales, junto con los chamanes o ancianos, quienes realizan en cerros y cuevas estos rituales y consultan a los antepasados o a los dueños del lugar como oráculos. Conmemorativos $^{13}$ son los rituales de acción de gracias por los pedidos concedidos y otras ceremonias que celebran periódicamente los eventos significativos para la comunidad o el grupo.

\section{CENTROSY FRONTERAS}

\section{Identificación de los centros}

El centro puede ser un lugar simplemente significativo para un grupo pero por lo común en nuestro universo de

${ }^{13} \mathrm{~V}$. Turner (1980) establece la diferencia entre dominio ritual y ceremonial señalando que el rito implica siempre un proceso de transformación de la posición o condición en tanto que la ceremonia conmemora, confirma y renueva un estado o una situación. estudio es sagrado, ya que en él se manifiestan los númenes, por lo que opera como axis mundi del etnoterritorio, articulando la dimensión horizontal con la vertical. Lo sagrado irrumpe en muchos lugares configurándolos como centros, aunque no todos tienen la misma sacralidad sino que pueden ocupar diferentes posiciones en una jerarquía de lugares sagrados. En este sentido, si bien cada centro es una réplica estructural de los otros, cada uno tiene su propia identidad construida por los seres que lo habitan, los mitos, los rituales y la historia. Una de las características del centro es que es un punto de "densificación significativa", un "centro cósmico" (R. Valdés del Toro, 1993: 33) vital para el grupo que tiene un imaginario sobre él y que lo ha dotado de sentidos y poderes terapéuticos, mágicos, y de afectividad y confianza. Esos centros cósmicos son lugares de contacto con lo sagrado y por lo tanto generadores de categorías de entendimiento (R. Cardoso de Oliveira, 1983) o "categorías orientadoras" de la cultura y de la identidad (R. Valdés del Toro, 1993: 73). La irrupción de lo sagrado implica una ruptura de niveles ontológicos y cosmológicos mediante la cual se 
intercomunican el supramundo, la superficie y el inframundo y circulan entre estos territorios los númenes, los chamanes y la gente común guiada por éstos, tal como puede apreciarse en multitud de relatos. El centro sagrado es el punto de intersección de los niveles cósmicos, unidos y comunicados por un eje central por el que pasa una abertura. Esta ruptura de niveles cósmicos y ontológicos es posible en los centros de los territorios sagrados, que pueden ser las montañas o sus proyecciones, como el templo y la pirámide.

Desde mi perspectiva, los lugares sagrados más reconocidos y frecuentados, cuya convocatoria es más que familiar, pueden ser definidos como santuarios: centros multisignificativos en los que reiteradamente se manifiesta lo sagrado y se producen eventos milagrosos, lo que da origen a mitos y rituales de diferente tipo. Son territorios complejos y polifacéticos que no sólo marcan emblemáticamente el lugar donde se ubican, sino que son factores principales de interacción, articulación social en general e intra e interétnica en particular. Dicho de otro modo, santuarios son los lugares sagrados de reconoci-

miento y convocatoria colectivos, que se construyen como centros de los etnoterritorios. En un sentido similar, aunque partiendo de una causística diferente, J. Prat (1989: 213) ve al santuario como un centro de interacción social y simbólica en el que se articulan y convergen diferentes fenómenos. Operativamente distingo los lugares sagrados naturales o santuarios naturales (aunque todos están "tatuados" por la gente), de los santuarios construidos, clasificación que no se basa en la convocatoria (local, subregional, regional, nacional, internacional), ni en las devociones que guían a los fieles ya que éstas son múltiples y no contradictorias (a las entidades territoriales, a los ancestros, a los ejemplares católicos), sino en las características externas del santuario (existencia o no de edificios religiosos) y en el control, o ausencia de él, en los santuarios naturales de la Iglesia sobre las calendarizaciones y las devociones efectuadas en el santuario.

En esta ocasión no trataré los santuarios construidos, que albergan las imágenes milagrosas en edificios religiosos y que se encuentran vinculados con las celebraciones del santoral de la Iglesia católica. En Oaxaca los santuarios construidos son muy numerosos, aun los de convocatoria regional y estatal, y constituyen centros de los etnoterritorios que se relacionan con las comunidades mediante los caminos de peregrinación (redes). Son particularmente importantes como constructores de centros de la territorialidad simbólica los que vinculan a los cristos negros por una parte, y por otra, a las vírgenes de la Concepción-Juquila (A. Barabas, 2003c).

Los santuarios naturales son lugares geográficos no construidos o con pequeñas construcciones, tales como piedras amontonadas, cruces o pequeños oratorios. Estos santuarios son generalmente los cerros donde moran los dueños o entidades poderosas y ambivalentes de la naturaleza que controlan el clima, los recursos y los bienes, en ocasiones consustanciados con los santos católicos. Por lo común se encuentran en el entorno de cada comunidad, aunque los santuarios emblemáticos de etnoterritorios o subregiones étnicas requieren un desplazamiento a veces prolongado. La gente peregrina a ellos por diferentes motivos, solos o guiados por chamanes, una o más veces por año, desde comunidades vecinas o lejanas, del mismo o de diferentes grupos.

Una de las vías para identificar santuarios naturales es hacer la etnografía de la narrativa sobre lugares sagrados o émicos; otra es realizar la de los procesos rituales que en ellos se practican — generalmente fuera del control de la Iglesia - en diferentes épocas del año, en forma individual, familiar o comunitaria, muchas veces guiados por especialistas religiosos. En otro trabajo (A. Barabas, 2003c) presenté una descripción de la variedad de procesos rituales que se realizan en cerros y otros lugares sagrados; entre ellos los terapéuticos - mediados o no por la ingestión de psicotrópicos-, los de pedido de daño, los adivinatorios, los de petición de lluvias y cosechas, los de cambio de autoridad, así como los varios ritos de umbral que preceden y suceden a los anteriores. La temporalidad de los principales procesos rituales colectivos se distribuye:

a) Entre el 1 y 6 de enero, para sacralizar el cambio de autoridades y propiciar su buen desempeño, para observar los vientos y hacer augurios sobre el clima del año.

b) El 3 de mayo, coincidente con la Santa Cruz, para el pedimento de lluvias y abundancia (a veces como oráculo). 
c) Entre fines de octubre y el 1 de noviembre para agradecer las primicias y recibir a los antepasados.

Además se acude a estos santuarios en días específicos de la semana durante todo el año para realizar ritos terapéuticos o de daño y de adquisición de poderes chamánicos.

Los lugares sagrados principales que son santuarios naturales y, por lo tanto, centros simbólicos de la etnoterritorialidad, forman parte del "complejo" cerro; este conjunto ocupa un lugar clave en la cosmovisón, ritualidad y representación del espacio de las culturas indígenas actuales. El complejo cerro con sus referentes naturales (la montaña con sus fuentes de agua, cuevas y árboles sagrados) y etnoculturales (el símbolo emblemático del pueblo, condensador de los ancestros tutelares, los naguales y los santos patronos protectores, donadores y defensores de límites) está presente en todos los grupos, en algunos con vívidas prácticas y narrativas, en otros consustanciado con los santos y la Iglesia, en otros más como metonimias en el altar doméstico o el atrio de la iglesia.

Los cerros, por lo común, son concebidos como parejas de diferente género, aunque se ubiquen muy separados uno de otro, y los habitantes de cada pueblo suelen construir una relación filial con el cerro más importante de su entorno geográfico. En la mayor parte de los casos, el cerro emblemático es entrada al inframundo de los muertos y es también concebido como cerro de mantenimientos, esto es, como lugar de reserva de todo tipo de riquezas naturales y, en la actualidad, también oro y dinero (A. Barabas, 2003c). Muchos pueblos indígenas peregrinan al cerro para practicar diversos rituales, además de celebrar a los santos en las iglesias de los pueblos y acudir a santuarios oficiales. Otros ya no van al cerro y realizan similares rituales dentro del espacio comunitario.

Pero no sólo los lugares sagrados y santuarios configuran centros; también lo hacen las gestas territoriales de las entidades sagradas y de los héroes que narran los mitos y relatos fundacionales, mismos que simbolizan la radicación de un pueblo en un territorio particular. Fundar significa trazar límites orientados, en este caso cardinalmente, y hacer de un espacio salvaje un espacio humanizado. Cada acto fundacional de un pueblo repite la cosmología creando una imago mundi en el microcosmos del espacio local.

\section{Mitos y relatos de fundación territorial}

Dentro de esta amplia categoría de relatos que nombran y fundan centros, esto es, pueblos y etnoterritorios, considero principalmente los que se relacionan con la búsqueda colectiva de un lugar propio para radicar y con la fundación de la comunidad o el etnoterritorio. En muchos relatos las acciones de creación y la marca de lugares específicos se llevan a cabo en el espacio del cerro emblemático, que opera entonces como metonimia del territorio más amplio que habita el grupo, aunque algunas narrativas también transcurren en el espacio de lo que está siendo nombrado como etnoterritorio o sus subregiones. Por ejemplo, el mito fundacional del rey Cuicateco se desenvuelve en el cerro Mujer, el del rey Chatín en el cerro Gavilán y otros lugares sagrados de la subregión Alta chatina, el del rey Kong Hoy en cerros, cuevas y lagunas del etnoterritorio mixe y el de Fane Kantisini en cerros emblemáticos de un territorio chontal mucho más amplio que el que poseen en la actualidad (A. Barabas, 2003c).

Los mitos y relatos de fundación son paradigmáticos porque constituyen el acto primigenio de creación del territorio por parte de una entidad sagrada que elige, marca y sacraliza el lugar y al pueblo que ha de habitarlo. Los fundadores míticos pueden ser por igual antepasados ilustres mitificados, dueños de lugar o santos y vírgenes que se hacen patronos. Tanto unos como otros nombran los lugares y parajes y dejan sus huellas en el paisaje, lo que constituye el acto de fundación y demarcación territorial, pero los cuerpos de relatos en los que los reyes y los naguales delimitan etnoterritorios transcurren en tiempos más antiguos, en tanto que el de los ejemplares católicos se construye a partir de la evangelización colonial y es fundador de comunidades locales. En este mismo apartado habría que considerar los numerosos relatos de antiguas campanas, a veces "encantadas" (invisibles) en los cerros y en las ruinas de los antiguos pueblos, que son típicamente fundadores de comunidades. 


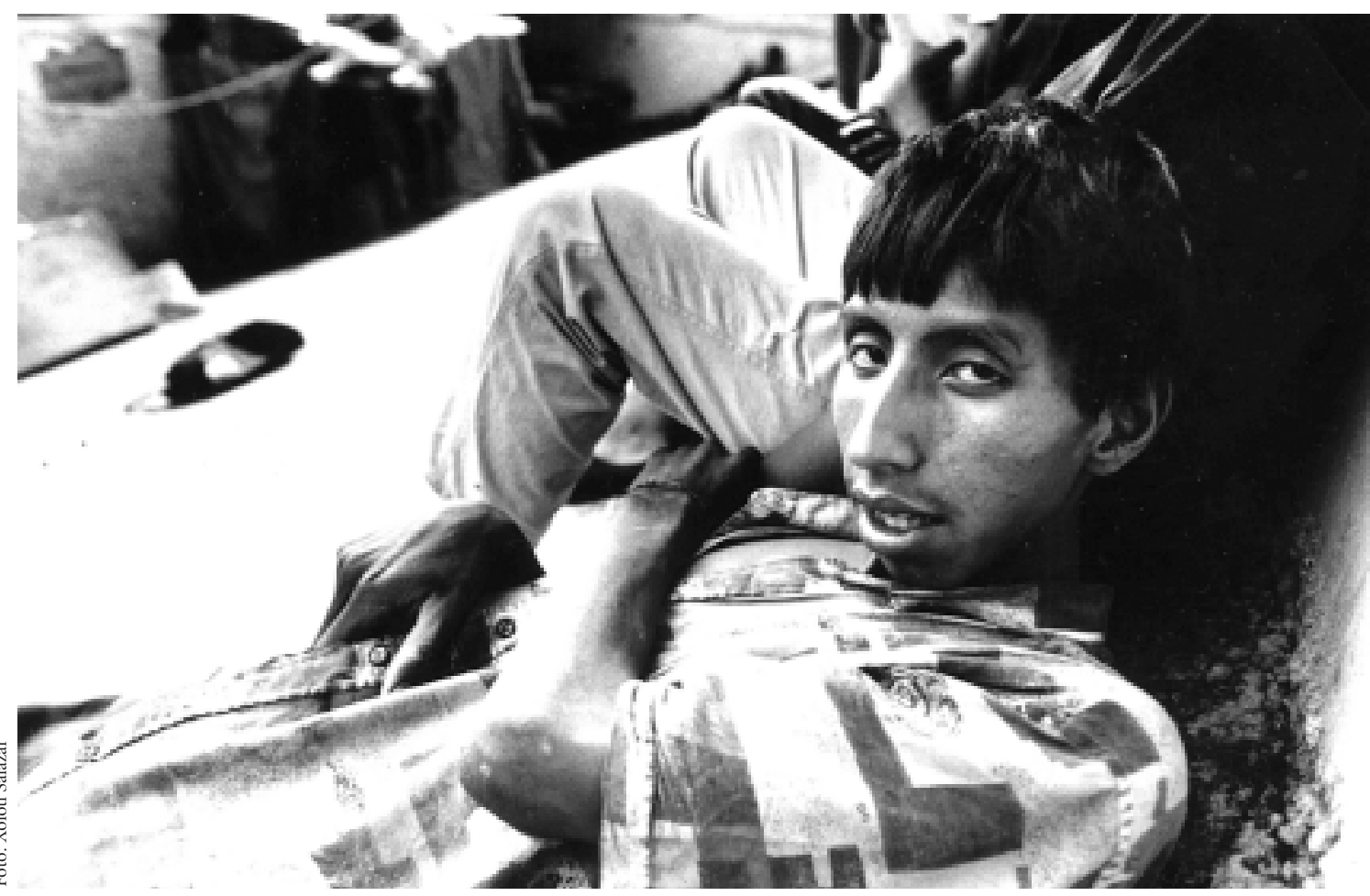

El Cubo; Metro Observatorio, México, D.F., 1996.

Con gran frecuencia, los episodios fundacionales están precedidos de relatos sobre migraciones en las que un pueblo se mueve de un lugar a otro en busca del sitio predestinado, y en este peregrinar van nombrando lugares. En muchos casos los mitos finalizan con episodios de cesión o privación de bienes. A grandes rasgos podemos separar los relatos fundacionales en:

a) Migratorios. Entre míticos e históricos, narran la migración —en cierta forma peregrinación - de un pueblo en busca de un centro, sitio señalado como "lugar prometido", al que se llega bajo la guía de jefes (ancianos sacerdotes) a quienes las deidades o los antepasados envían sueños, revelaciones u oráculos que señalan el camino y constituyen augurios. Con frecuencia la prolongada migración incluye residencias temporarias en lugares que parecen ser adecuados, aunque más tarde demuestran no serlo, por lo que el grupo reinicia el camino hasta que un hecho excep- cional esperado les indica que han llegado al lugar de fundación. Cuando se trata de relatos migratorios fundacionales del etnoterritorio, los lugares abandonados por el grupo principal pueden constituir pueblos fundados donde se asientan otros sectores de la etnia u otros grupos. Es el caso del relato de los hermanos cuicatecos Teutil y Papaloctipac, que migran largamente con su gente fundando numerosos pueblos cuicatecos (hoy existentes) pero también otros, como Mazatlán Villa de Flores y Ayautla, después ocupados por mazatecos (H. Concepción, com. personal, 2000). El relato recogido entre los zoques "chima" de San Miguel Chimalapas, Oaxaca, narra la migración mítica dirigida por los Ancianos zoques desde Copainalá en Chiapas hasta el lugar elegido por el santo para la fundación de San Miguel. Las narraciones migratorias también suelen brindar datos puntuales sobre características e hitos geográficos del etnoterritorio reflejados en la toponimia propia, como muestran decenas de narraciones 
colectadas en los valles y en la Sierra Norte zapoteca, en la Chinantla Baja y en la región mixe.

b) El águila roba-come-niños. Los episodios del águila come-niños son comunes a cuicatecos, chinantecos, mazatecos, zapotecos de la Sierra Norte, mixes, chontales, triquis y tacuates. El mitema es bastante similar en las numerosas versiones y aparece en el contexto de una migración de lugar en lugar en busca del sitio definitivo para la fundación del pueblo. Están en un sitio, aparece el águila, roba y come a los niños dejando sus huesos en las cuevas, y tienen que continuar el camino aun cuando logren vencerla con su astucia colocándose canastos (chiquihuites) sobre la cabeza, para que el águila se los lleve en lugar de los niños o para que no los vea. El mitema aparece en el ciclo de los gemelos chinantecos, que vencen al águila y le roban los ojos para convertirse en Sol y Luna; y se relata también como parte de las hazañas del Chikón Tokosho mazateco quien, al burlar al águila roba-come-niños, hizo posible a su gente residir en el territorio de alta montaña que Dios les había dado a cambio de oro (C. Incháustegui, 2001: 135). Lo que justifica considerarlos como relatos fundacionales que muestran centros es un motivo siempre presente: después de mucho migrar perseguidos por el águila, los gemelos míticos u otras personas salvan a los niños; a veces la vencen o la matan, con lo que la gente consigue afincarse en un lugar y dejar de proporcionarle sacrificio y alimento. Así como las águilas obligan a migrar también orillan a fundar pueblos. ${ }^{14}$

c) Dueño del lugar y su nagual. Estos mitos narran la gesta de las entidades territoriales, dueños del cerro, frecuentemente acompañadas o sustituidas por su nagual, la culebra, como cuidadora, que a su paso por la comunidad o por la región van creando-fundando lugares sagrados e históricamente emblemáticos para una

${ }^{14}$ En Xagacía, Villa Alta, Sierra Norte zapoteca, el mito de fundación señala que los primeros pobladores tuvieron como señal un águila en vuelo que les señaló el lugar de fundación donde había agua. En las rocas de los cerros en torno al pueblo los nativos identifican señas de la figura del águila. También en Xiacuí el águila indica a la gente el lugar de fundación del pueblo. comunidad específica o para el grupo. Las marcas dejadas por los dueños constituyen hitos geográficosimbólicos muy importantes para la memoria y la identificación comunitaria y étnica. Los ejemplos de esta modalidad de fundación territorial comunal o étnica son numerosos. Tal vez los paradigmáticos sean el del cerro Verde de los chocholtecos cuyo nagual, la culebra, dejó huellas de su paso por el territorio étnico en su camino hacia la costa (se trata de la culebra vencida por el rey Sapo en un episodio de competencia y privación de bienes que forma parte del mismo ciclo mítico); ${ }^{15}$ y el de la inmensa culebra de Lachiriega y Quiatoni, pueblos zapotecos del valle (A. Barabas, 2003c).

d) Vírgenes y santos. Son asimismo mitos que denotan centros. Vírgenes y santos pueden ser aparecidos o llegados al sitio milagrosamente, pero su característica central es que escogen el lugar donde desean que se construya su capilla y el pueblo que debe acogerlos; de esta manera fundan comunidades de las que, con frecuencia, resultan después ser santos patrones y objeto de importantes celebraciones y mayordomías. El recurso del santo o la virgen para elegir su lugar y la

\footnotetext{
${ }^{15}$ Este ciclo relata una saga fundadora que tiene lugar en los cerros y que culmina con la retirada del dueño del agua y la privación del grupo. "El cerro emblemático de los chocholtecas es el Verde o Nudo Mixteco, cerca de Nativitas y Coixtlahuaca, que tenía amores con el Pico de Orizaba (mujer) y un hijo, el cerro Palomo. Verde es el dueño del cerro y del agua y tiene por nagual a la culebra. Existen diferentes versiones de los motivos del desencuentro amoroso: a) cerro Verde deja a Orizaba, despechado porque ella que es muy blanca se burla de él que es prieto, b) Orizaba deja a Verde porque él la engaña con otros cerros mujeres vecinos, Correoso y Llorón, c) los chochos inventan rumores que los distancian. Finalmente Orizaba se aleja y en su camino deja caer las joyas, el dinero, las semillas y los frutos que había traído de sus tierras. Los bienes resultan "encantados" en las peñas Ahumadas y otros lugares (cerros, peñas, cañadas) del territorio que son nombrados y creados. Por último, el mito fundador culmina como mito de privación, ya que los chochos pierden las riquezas traídas por Orizaba. En otro episodio del ciclo el cerro Verde, resentido por los rumores de los chochos, también abandona la región y su nagual deja huellas por el camino, que se pueden observar cerca de San Miguel Marcos Pérez, por Teposcolula, Yolomécatl y Tlaxiaco. Verde, antes de irse, le deja toda clase de semillas a una señora y ésta, enojada por su partida, las arroja a la lumbre en el paraje Cañada de Lumbre, y quema las riquezas naturales del territorio chocho, que hasta ese momento era exhuberante. Otro mito relacionado es la competencia entre el sapo y la culebra (cerro Verde) y la pérdida de la vegetación y del agua (A. Barabas, 1999).
} 
gente que ha de cuidarlo, es hacerse pesado o regresar por sí mismo al sitio escogido, que suele estar relacionado con el cerro, con alguna fuente de agua y con algún árbol.

Se encontraron estos tipos de narraciones fundacionales de centros en el nivel del territorio local. El territorio global o etnoterritorio si bien comparte con el local los tipos a), b) y c), se expresa también con otros relatos fundacionales emblemáticos de todo el grupo, muy relacionados entre sí, que muchas veces se desarrollan en los lugares sagrados del "complejo" cerro. Por otra parte, no tenemos registro de apariciones fundadoras de vírgenes y santos en el nivel del etnoterritorio, con la posible excepción de Juquila, que se mueve por diferentes puntos del ámbito chatino. Para el etnoterritorio podemos agregar estos otros dos tipos de relatos:

a) Sol y Luna creadores y fundadores. El ciclo de los gemelos Sol y Luna ha sido registrado y analizado en varias de las culturas indígenas de Oaxaca. M. Bartolomé
(1984) se refiere a este ciclo entre los cuicatecos, chatinos, chinantecos, triquis, mazatecos y mixes, considerando que estos héroes ancestrales suelen ser los responsables de numerosos actos de creación (de bienes culturales, de lugares, de animales) mediante los cuales los humanos quedan separados de los animales y tiene comienzo el mundo originado con la luz. Es frecuente que estos antepasados míticos gemelos sean creadores de fenómenos naturales a su paso por el mundo terrenal en camino hacia el cielo, y que vayan fundando el territorio étnico y poblándolo de accidentes geográficos, de recursos, de bienes y de comunidades (Sol suele crear los cerros y los manantiales).

b) Héroes culturales o antiguos reyes. Estos mitos de fundación narran las hazañas de los héroes culturales tesmósforos (a veces consustanciados con los gemelos). Son figuras de difícil definición, ya que se trata de personajes míticos a los que se recuerda también como jefes históricos, aunque no existan pruebas de ello. Los héroes pueden también comportarse como tricksters, pero son eminentemente creadores de bienes culturales que entregan a su pueblo, y fundadores de los lugares sagrados y las fronteras del etnoterritorio, que defienden de agresores externos. Algunos de ellos son también héroes mesiánicos, que prometieron a su pueblo regresar para auxiliarlos en situaciones de peligro. Se conocen varios ejemplos exponenciales, entre ellos el Kong Hoy de los mixes (A. Barabas y M. Bartolomé, 1984).

Los antiguos reyes heroicos son considerados como iniciadores del linaje étnico; esto es, antepasados ilustres que solos o en pareja viajaron por el etnoterritorio en el tiempo inicial fundando lugares y dejando marcas de su paso por ellos, dado que entonces la piedra era blanda. Generalmente la gesta fundadora, que se realiza como una migración, se lleva a cabo en el cerro emblemático de la región étnica (o interétnica), que es la representación principal del cosmos y metonimia del territorio. Mencionaré otros ejemplos, el mito fundador del rey Chatín (M. Bartolomé y A. Barabas, 1996: 159-161), ${ }^{16}$ el de Fane Kantisini, rey chontal (A. Barabas y M. Bartolomé, 1993), y el del rey Cuicateco, ya registrado por Weitlaner (1977) y recogido por nosotros en una versión similar.

\footnotetext{
${ }^{16}$ El rey Chatín dejó las costumbres y las creencias a toda la gente indígena chatina... y dió nombres a los pueblos de acuerdo con sus características. Él iba huyendo del agua que se salió del mar después de un gran cataclismo, amenazando con invadir todo su reino, por eso el rey buscó un lugar tan alto como cumbre Gavilán, donde se juntan el río Mano y el río Juquila. En el cerro Gavilán dejó la Piedra del Rostro del Rey, allí este rey dejó su huella, allí está su trono con respaldo y apoyabrazos, su silla, su baño, su huarache, la huella donde apoyó su cabeza para dormir. A ese lugar sagrado va todavía la gente a hacer sus pedimentos de salud y de bienes al dios Santo Padre Sol $\mathrm{y}$ al rey chatino. Los mayordomos antes iban a hacer rosario, los topiles llevaban sus canastos de pan, tamales de calabaza, sus jarros de café y las autoridades se trasladaban con sus varas de mando. Él dijo que su templo está en la Piedra del Sol. El rey también dejó su casa en un lugar que se llama Chcu lati (Arroyo Delgado). Allí dejó la figura de su cara sobre una piedra pequeña y se fue a recorrer todos los lugares a donde había indígenas chatinos y dejó la costumbre de dar de comer (ofrendar y sacrificar) a la Santa Piedra. También dejó otra figura suya, otra piedra grabada con su cara, en un lugar que se llama Rancho Viejo. Después que el rey recorrió todos los lugares donde estaban los chatinos y vio que ya todos tenían sus comodidades, que todo estaba ordenado, se fue a acostar allí a la Piedra Gavilán y cuando él estaba acostado ya su danza se estaba bailando en Monte Albán. Porque él se comunicó con el rey mixteco y el rey zapoteca, y se fue a vivir con ellos a Monte Albán. Pero de Monte Albán los españoles lo llevaron a México, allí lo descoronaron, porque ya no regresó (Bartolomé y Barabas, 1996: 159-161).
} 


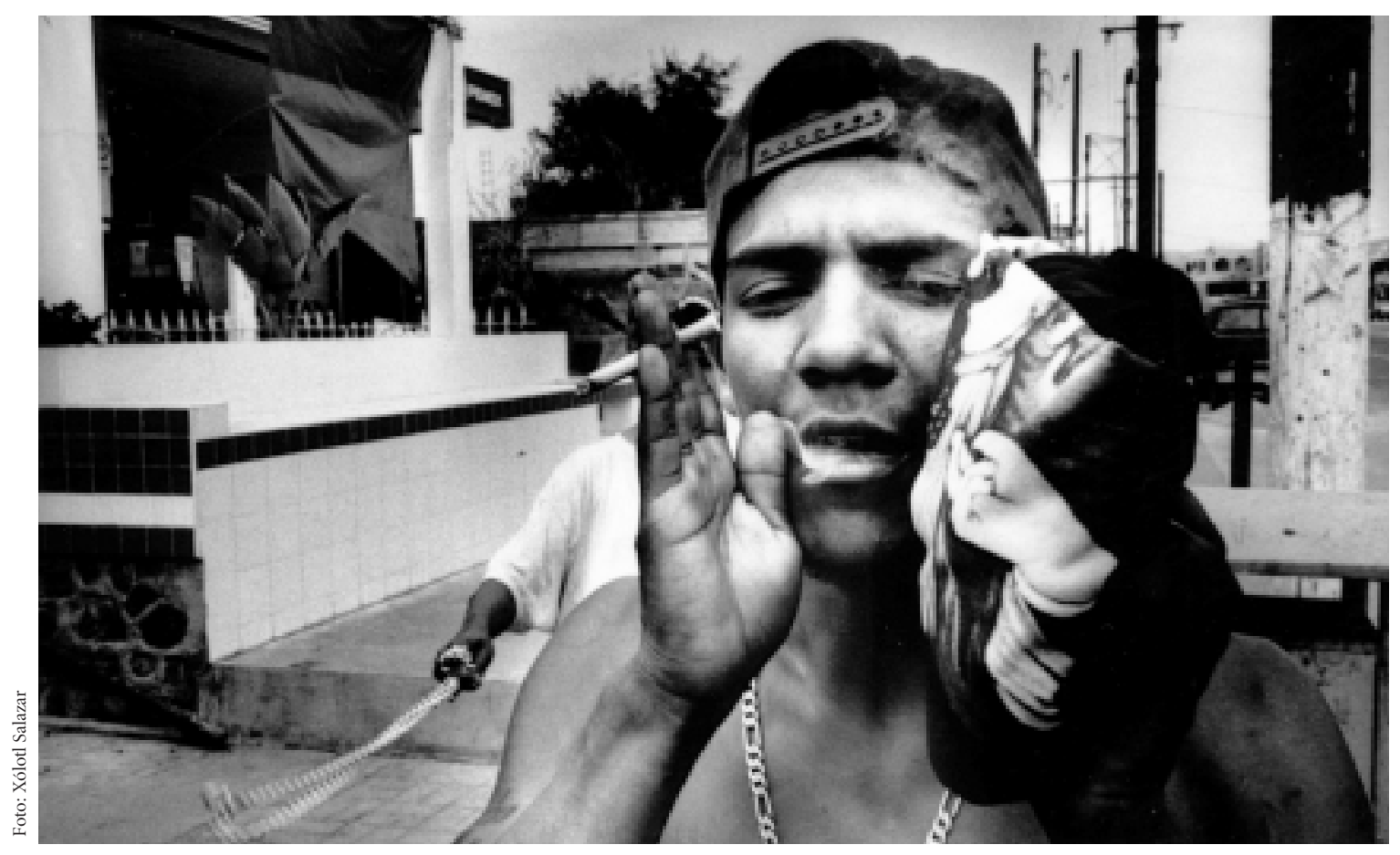

El Chonte; Tijuana, 2000.

En resumen, mediante la etnografía de los procesos rituales y la narrativa se han identificado como centros de los etnoterriorios los lugares sagrados que son santuarios naturales y santuarios construidos, así como los lugares emblemáticos de fundación territorial. En la mayoría de los casos, con la relativa excepción de los santuarios construidos, esos centros están ubicados en el que hemos llamado el "complejo" cerro, que simboliza el territorio.

\section{Identificación de las fronteras}

Toda frontera, para W. Douglass (1999), no sólo es conceptual —una creación que forma parte de los mapas mentales- sino que también es epicentro de la multilocalidad y la multivocalidad, un ámbito de encuentros más que de separaciones. Las fronteras, los límites, son elementos simbólicos consustanciales con el marcamiento de territorios y están implícitos en toda relación entre "nosotros" y los "otros", por lo que concordamos con J.
Escalera (1999: 100) cuando dice que "el territorio es un factor clave en la estructuración de la identidad social". Como señala este autor (op.cit.: 101), con frecuencia los límites no se corresponden con factores geográficos sino que son construcciones histórico-culturales, o éstas tienen más peso aún que las físicas.

Los etnoterritorios simbólicos, que tienen referentes geográficos y no sólo culturales, poseen fronteras dinámicas, porosas y flexibles, que son ámbitos de interacción y que los usuarios pueden traspasar y modificar, a diferencia de las fronteras agrarias y de las político-administrativas, como las de los municipios, las provincias, los Estados nacionales, que suelen ser densas, rígidas y aparentemente inamovibles. No obstante, en las culturas de Oaxaca las fronteras entre grupos etnolingüísticos, aun las fronteras simbólicas, tienen cierta densidad y son conocidas por las diferentes comunidades. La casuística etnográfica permite señalar que la noción de etnoterritorio contiene la de fronteras delimitables entre grupos diferentes, que se conciben como marcadas y protegidas por 


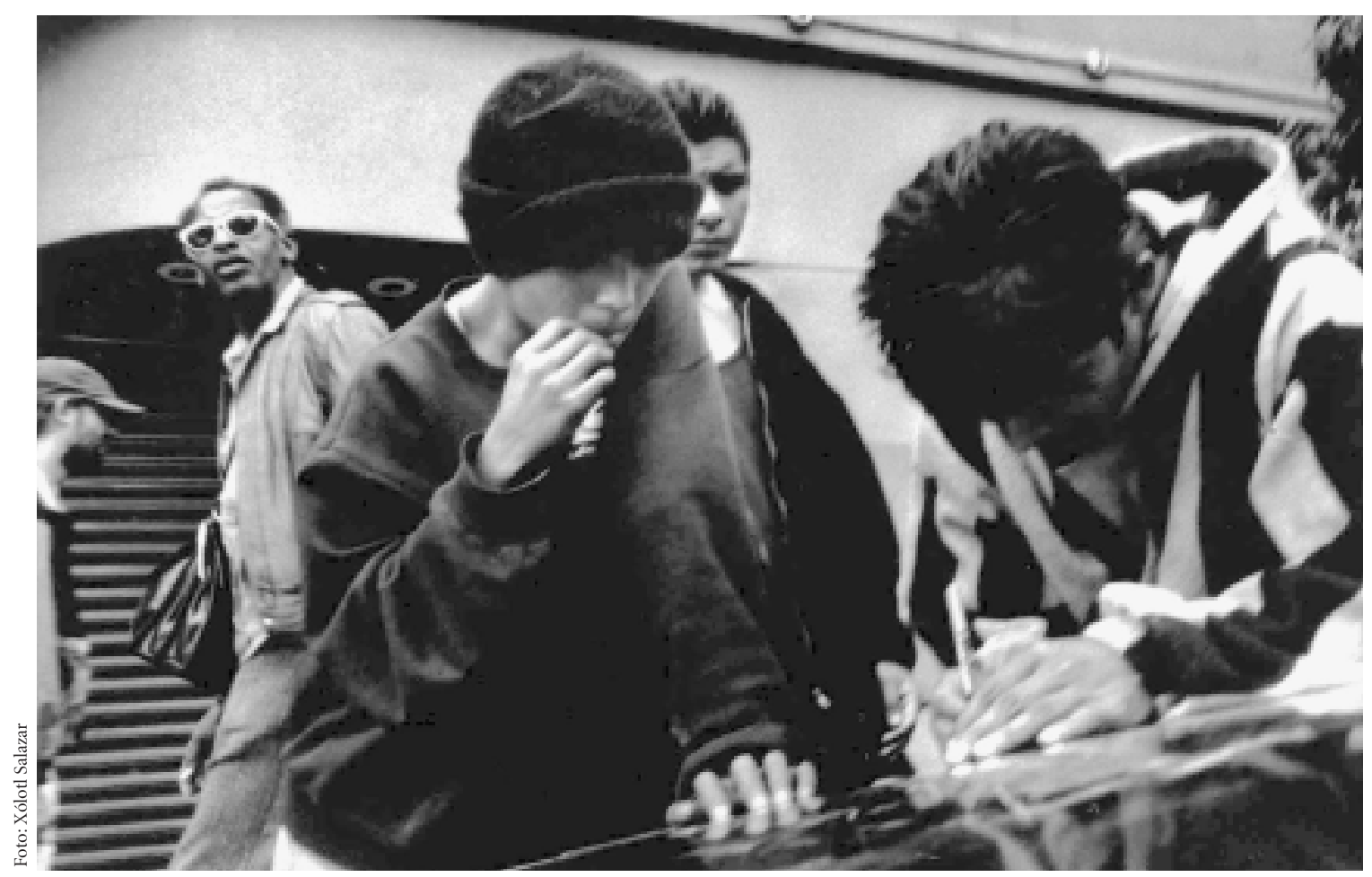

El Piolín, el Chilango y el Chonte en la Calle $2^{\mathrm{a}}$; Tijuana, 2000.

las entidades sagradas. En muchos casos las marcas del etnoterritorio de los grupos etnolingüísticos o de los linajes ${ }^{17}$ se expresan en la toponimia.

Desde mi perspectiva son fronteras, a partir de un centro, las cuatro orientaciones que son esquinas del cosmos, del etnoterritorio, del monte, de la milpa, del pueblo y de la casa-solar. Si bien marcan límites o separaciones entre espacios y grupos contrastados, las fronteras pueden ser también ámbitos espaciales de articulación entre grupos, ocasionalmente compartidos o evitados. Ya he mencionado que las fronteras simbólicas son difusas, de mucha menor densidad y rigidez que las fronteras geopolíticas

\footnotetext{
${ }^{17}$ E. Avendaño (2001: 43) da los nombres triquis de los once linajes del clan que constituye la comunidad de Santo Domingo del Estado, Putla, que se relacionan con las características de la geografía y el clima de los lugares. Así, se reconocen el linaje de la Ladera, el de la Loma, de la Orilla del Monte, de Piedra de Nopal, de Donde corre el Viento, de Abajo del Árbol Liso, del Pie del Fresno, etc.
}

o agrarias. No obstante, los pueblos indígenas han marcado históricamente y aún marcan límites o fronteras territoriales simbólicas. En el nivel local, el espacio del monte y de la milpa, cercanos a los límites con lo poblado pero en zona de frontera, son "peligrosos" porque en ellos aparecen los dueños, las tonas, los chaneques — que son emanaciones de las entidades territoriales de carácter entre travieso y maligno, ayudantes de los dueños$\mathrm{y}$ otros personajes malignos usualmente femeninos que cambian de apariencia para posesionarse de los que viajan por el espacio del monte y enfermarlos, como la Llorona. En estos territorios se realizan diferentes rituales propiciatorios y protectivos que ofrendan a las cuatro orientaciones cardinales.

En el ámbito de la comunidad, los límites de la casa y del solar suelen marcarse con cruces y mediante las ofrendas enterradas en las cuatro esquinas y en el centro. En el territorio del barrio y del pueblo los límites son señalados con cruces, mojoneras y oratorios, y refrendados 
durante las procesiones, que recuerdan centros, márgenes, límites y fronteras interiores (domésticas, barriales, mitades, comunitarias). Las procesiones constituyen ritos de cerramiento de las fronteras del pueblo o del municipio que, en la concepción local, impiden la "entrada" de fuerzas adversas. Asimismo —y éste puede ser su papel principal- conforman circuitos mnemónicos integrados por caminos o hitos que marcan con cruces y oratorios las fronteras comunitarias a partir del centro, la iglesia, y las recuerdan y reafirman periódicamente durante las celebraciones religiosas. ${ }^{18} \mathrm{Al}$ renovar los límites del barrio, del pueblo, de un grupo de comunidades vecinas, ${ }^{19}$ se renueva y legitima también la posesión de ese espacio por ese pueblo, al mismo tiempo que se recuerdan las fronteras entre el pueblo y el monte y con los pueblos vecinos. En ocasiones, las procesiones barriales refrendan no sólo el oratorio o la capilla, que es el centro, sino también la existencia y los límites de las viviendas y los solares familiares.

En el nivel global, las fronteras simbólicas intercomunitarias y las del etnoterritorio, marcadas y nombradas por los héroes fundadores, son recordadas en los mitos y reafirmadas por las entidades territoriales protectoras en sus periódicas disputas.

Lo que nos permite detectar fronteras a nivel simbólico en el territorio local y en el global es un conjunto de relatos que narran competencias y peleas fronterizas entre pueblos del mismo o de diferente grupo etnolingüístico. El primer caso nos remite a relaciones intraétnicas

\footnotetext{
18 En Tlahuitoltepec (mixes) las procesiones visitan las nueve ermitas: San Lucas, El Santuario, Santa Cecilia (20 de noviembre, patrona de los músicos que le hacen su mayordomía y procesión), Santa Ana (26 de julio, con gran mayordomía), Santa Cruz (3 de mayo), Esquipulas (15 de enero, coincidente con el cambio de autoridades, llevan la imagen del Cristo hasta su ermita y luego hacen comida y fiesta), Guadalupe (12 de diciembre), Juquila (8 de diciembre, poco visitada la ermita porque peregrinos van a Juquila) y Flores (23 de mayo, María Auxiliadora); todas constituyen centros ceremoniales en los asentamientos periféricos dependientes del municipio (E. Kuroda, 1993: 57). 19 Uno de los elementos, aunque no el único, que nos permite distinguir la procesión de la peregrinación es que aquélla se realiza dentro del espacio del pueblo o entre pueblos vecinos que se reconocen afines, en tanto que ésta parte de la comunidad — con o sin santo-, realiza un trayecto por diferentes espacios y territorios simbolizados, arriba a un santuario o centro sagrado, y regresa a la comunidad.
}

y el segundo a relaciones interétnicas, que pueden establecerse entre distintos grupos indígenas o entre indios y blancos. Esto es, que las narraciones míticas nos permiten apreciar fronteras simbólicas de territorios comunales y de etnoterritorios. Los relatos de competencias en fronteras territoriales, o por bienes y posiciones sociales dentro de ellas, se registran en todos los grupos y se expresan como disputas, conflictos, robos mutuos y competencia por la sabiduría y la supremacía étnica.

Estos mitos exponen relaciones étnicas contrastivas entre comunidades y grupos vecinos en competencia por nichos ecológicos. Las acciones de las entidades territoriales y los naguales están encaminadas a cuidar los recursos del territorio y vigilar que no se violen los límites de los pueblos a los que protegen: que no pasen extraños, enfermedades o naguales de otros pueblos, que no se roben o violen sus posesiones y lugares (recursos, campanas, santos y vírgenes, manantiales, cerros) y que no se coloque en cuestión la supremacía étnica propia. Muchos de esos relatos narran la superioridad del pueblo narrador frente a las comunidades en competencia, otros muestran sus pérdidas. Cuando la mitología simboliza el conflicto interétnico la encontramos principalmente entre pueblos de frontera, en tanto que los relatos son menos conocidos en poblados centrales del etnoterritorio. Puede decirse que en las fronteras, ya sean las comunales o las étnicas, la manifestación territorial de la sacralidad opera como potencia de "cerramiento" o barrera que protege al endogrupo y lo separa de los otros.

La que sigue es una sencilla clasificación de la narrativa sobre competencias territoriales en los límites de los pueblos que muestra fronteras territoriales intra e interétnicas:

a) Competencias y peleas intra e interétnicas entre naguales. Múltiples relatos en todos los grupos muestran el típico episodio de protección de las fronteras entre pueblos vecinos del mismo o de diferentes grupos, que se desarrolla como competencia entre naguales, generalmente rayos, centellas y ventarrones que suelen agredir las iglesias (centros) de los pueblos contrincantes. Un relato contado por chatinos y mixtecos, que acaba con un motivo de privación de bienes, narra que 
los naguales de los pueblos fronterizos de Tututepec (mixteco) y Zenzontepec (chatino) se peleaban entre sí como rayos por la posesión de la culebra de agua que moraba en el cerro mixteco Yucusáa (en chatino cerro Pájaro) y garantizaba la abundancia de lluvias para este pueblo. Los "cuidadores" chatinos vencen a los mixtecos, roban la culebra, el agua y la abundancia de Tututepec, y se las llevan para su cerro de la Neblina en Zenzontepec.

Otros relatos marcan la frontera interétnica con los "blancos":

... los ancianos habían ordenado a los brujos vigilantes de la raya que mandaran a sus naguales rayos a matar al presidente de la república Luis Echeverría. Éste era considerado como un brujo cuyo nagual trataba de introducir calamidades y desgracias (la presa Cerro de Oro) de "este lado de la raya" (el territorio de Ojitlán). Los brujos chinantecos no pudieron cumplir su cometido ya que, según se comentó más tarde, el presidente estaba muy protegido por sus espíritus guardianes a los que identificaban como vigilantes de la raya de otro pueblo: la ciudad de México (A. Barabas, 2002: 194).

b) Competencia por campanas. Si bien se trata de una narrativa que marca fronteras entre pueblos o entre grupos que compiten por las campanas, en muchos casos son también relatos creadores de centros ya que simbolizan la fundación de antiguos pueblos que más tarde fueron abandonados. Casi todas las comunidades de todos los grupos tienen relatos de campanas abandonadas en los pueblos viejos, perdidas o robadas, a veces recobradas por sus naguales o autoridades, que han perdido el sonido, están quebradas, enterradas o "encantadas" en los cerros y cuidadas por las culebras auxiliares del dueño del cerro. La campana es un símbolo muy importante en Oaxaca, ya que condensa significados de "pueblo" desde la época colonial en que fue adoptada - junto con el símbolo de la iglesiapara denotar espacio poblado, en reemplazo del cerro y el agua. En el imaginario de las comunidades actuales se encuentra relacionada con pueblos deshabitados en los que - dice la gente- se escucha su sonido. Entre los numerosos relatos, en el Istmo se narra que el rey de los huaves, Nitok, fundó la iglesia del pueblo vie- jo de Tehuantepec, pero la campana fue robada por los reyes de Chiapas. Cuando éstos iban a ser alcanzados por el rey huave tiraron la campana en la tierra y formaron la laguna de Zanatepec, en tanto que su sonido fueron a dejarlo en la cueva del cerro Cristo. Se escucha su sonido cuando van a dejar ofrendas al cerro en abril y también cuando va a haber temporal. También son muy conocidas las disputas por las campanas y su sonido en las fronteras entre pueblos tacuates y amuzgos y tacuates y mixtecos.

c) Competencia por el agua. Son reiterados los relatos que simbolizan las relaciones competitivas entre comunidades y grupos por este escaso y valioso recurso. Sin pretensión de elaborar una lista de relatos que muestren las fronteras marcadas a partir de la competencia por el agua, quiero mencionar el caso de Coixtlahuaca (chocho) y Tamazulapam (mixteco), simbolizado por la disputa de la culebra y el sapo, en el que se marcan varios parajes de la frontera entre estos grupos, y que culmina con la pérdida del agua del territorio chochoteca en favor de los mixtecos.

d) Robo o intento de robo del santo. Con cierta frecuencia las apariciones milagrosas de Cristo, o de santos y vírgenes, favorecen a los pueblos pobres y pequeños y las cabeceras parroquiales, habitadas por mestizos y apoyadas por la Iglesia, pretenden confiscarles las imágenes con el pretexto de darles mejor cuidado. Es el caso, entre muchos otros, del Señor de las Tres Caídas de San Andrés Teotilalpan (cuicateco), un Cristo negro aparecido, que trató de ser expropiado por el vecino Teutila. También son numerosos los relatos de comunidades que "envidian" a sus vecinas la posesión del santo milagroso y traman diferentes estrategias para arrebatárselo. Frente a estas competencias por la posesión de lo sagrado, la propia "voluntad del santo" parece definitoria en muchos casos. Los discursos sobre el regreso misterioso al lugar-pueblo escogido, la pesadez que impide su traslado, son fenómenos asociados a la elección protectiva y fundacional del santo. En todos los casos el intento de robo de los santos expresa de manera exponencial la competencia intra o interétnica por recursos valiosos y la delimitación de fronteras simbólicas entre pueblos y grupos. 


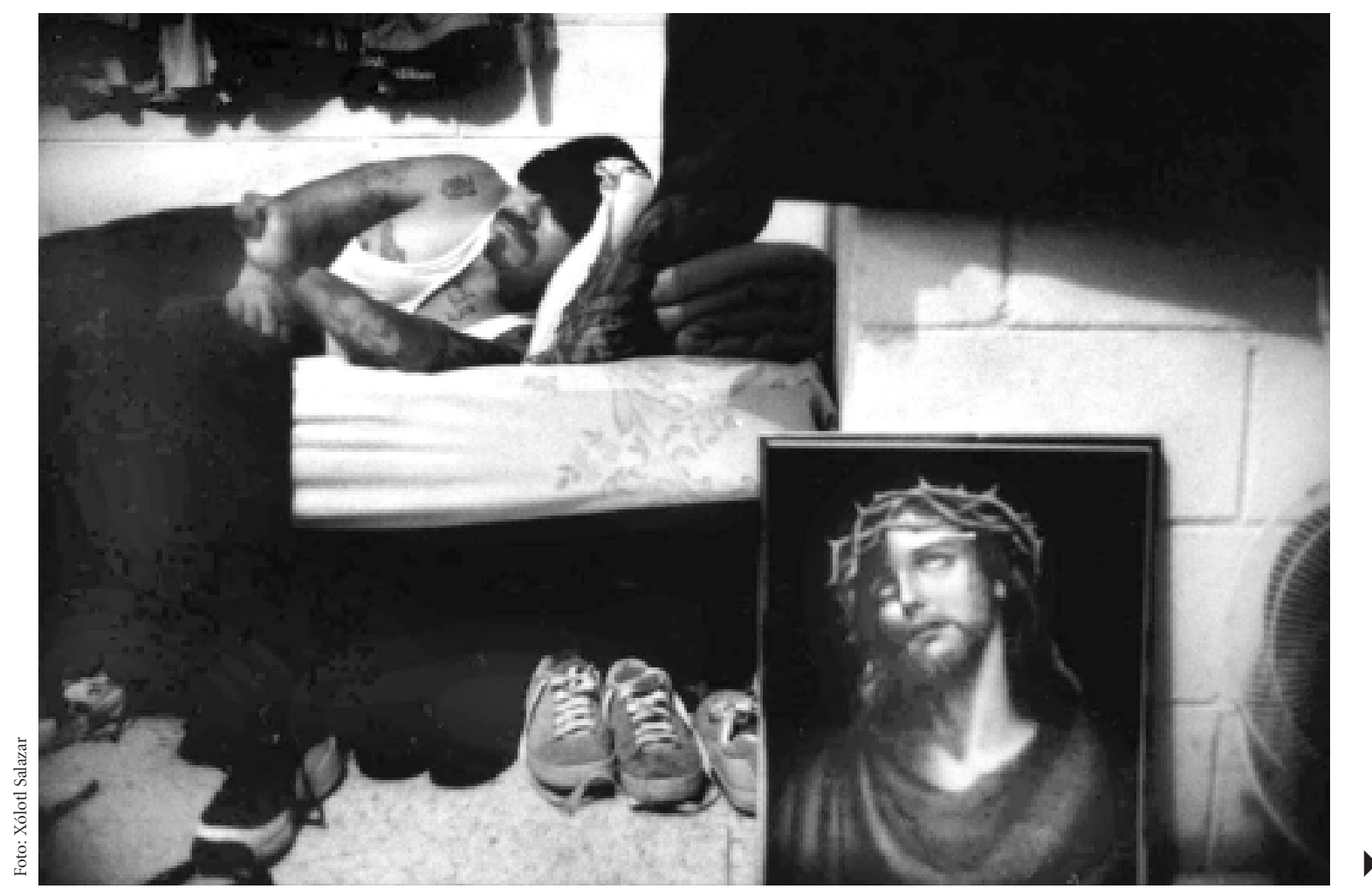

El Cholo en su cama, Centro de Rehabilitación para el Alcoholismo y la Drogadicción (CIRAD); La Morita, Tijuana, 2000.

A lo largo del ensayo se han presentado relatos que hablan de la pérdida de agua y de las riquezas materiales asociadas con ella. Esta narrativa surge de la concepción sobre lugares de grandes riquezas naturales asociados a un tiempo anterior imaginado como paraíso de abundancia, que deja lugar a la pobreza de la vida actual por abandono de las entidades sagradas dueñas de esas riquezas. No pocas veces la responsabilidad de ese abandono suele ser atribuida a los mismos indígenas, que dejan de creer y de cuidar a las entidades del territorio. Relacionado con estas concepciones existe un tipo de relatos que marcan territorialidad de frontera, comunal o étnica, que llamamos mitos de privación y que implican la pérdida de bienes de un pueblo en favor de comunidades vecinas del mismo grupo o de comunidades de otros grupos. Los mitos de privación simbolizan la pérdida de una mejor condición y medioambiente que existía en el tiempo inicial y explican la actual situación de carencias y deterio- ro ambiental. En la actualidad constituyen una expresión de las relaciones interétnicas desiguales y de los conflictos intercomunitarios, no sólo entre indios y blancos sino también entre grupos indígenas que trazan fronteras simbólicas.

Asimismo, los mitos de privación expresan un conflicto con las entidades territoriales, no ajeno al catolicismo, que conduce al despojo de los bienes del grupo: errores, ofensas, falta de "pago", desatención o falta de respeto con los númenes, implican quiebras graves de la ética del don, ya que se rompe la relación de reciprocidad con lo sagrado. Los númenes agraviados deciden llevarse a otra parte las riquezas que tenían en el cerro y entregárselas a otra comunidad u otro grupo. Esas riquezas suelen ser naturales: agua, lluvia, semillas, milpas, ganado, frutos; pero con frecuencia son también —o en lugar de - tesoros en joyas y dinero. Resultan particularmente frecuentes los relatos de la culebra que se lleva el agua, en tanto que 
otros mitos de privación o pérdida están incorporados a las sagas de los héroes fundadores. Entre los relatos paradigmáticos de la pérdida de agua en favor de otros pueblos o grupos, se encuentra el de los pueblos zapotecos cajonos (de la Sierra Norte) que son abandonados uno a uno por la culebra del agua que emigra hacia territorio mixe y, como ya mencionara, el de la gran culebra de Quiatoni y Lachiriega que abandona a su pueblo en favor de la región del Istmo hacia donde se va dejando su huella (A. Barabas, 1993c).

Las fronteras son lugares ambiguos, transicionales, de conflicto potencial, por eso hay que establecerles marcas de uso-posesión. Para marcar el territorio se realizan ritos de umbral y se usan objetos o símbolos que separan lo propio de lo ajeno, como el idioma. Por ejemplo, en la concepción de los chontales de la subregión Alta cada tierra habla el idioma de su gente y no se puede "levantar" la tona de un enfermo más que hablándole a la tierra en ese idioma. De esta manera trazan un límite idiomático y terapéutico entre ellos y los zapotecos de la Sierra Sur que los rodean. Algunas ceremonias, como las procesiones, revisan periódicamente los límites comunales donde hay cruces o ermitas. Las fronteras pueden estar marcadas por santuarios emblemáticos, que mantienen vivo el contraste entre grupos vecinos (cuicatecos y chinantecos frente al cerro Mujer), o pueden ser porosas y traspasarse con cierta facilidad, por lo que se establecen "tiempos-lugares" donde se suspende el conflicto. Así, por ejemplo, el cerro Cristo es emblemático para los huaves y para los zapotecos del Istmo, pero cada grupo peregrina a él en un momento particular para no encontrarse con los otros. Esta regla tácita se aplica también entre los zapotecos simpatizantes del PRI y los del PRD. En ocasiones los conflictos étnicos limitan el uso global de los lugares sagrados emblemáticos y orientan su reproducción en otras áreas; tal parece ser el caso de las Cuevas del Rayo de los triquis, que se replican en las diferentes comunidades (A. Barabas, 1993c).

La relación concreta que cada grupo establece con sus vecinos fronterizos respecto de los lugares sagrados compartidos o de las áreas de frontera interétnica o intercomunal debe ser estudiada en cada caso; sin embargo, lo que quiero proponer es que las fronteras territoriales sim- bólicas que muestran los mitos no son ficciones, sino que generalmente reflejan los difusos contornos de las fronteras lingüístico-culturales entre grupos, tal como puede apreciarse relacionando los nombres de los pueblos que compiten y de los lugares sagrados, mencionados en los relatos y utilizados en los rituales, con las adscripciones etnolingüísticas conocidas (A. Barabas, 1993c). Para dar unos pocos ejemplos puedo mencionar la frontera marcada entre Coixtlahuaca (chocholteca) y Tamazulapan (mixteca) por el mito de la culebra y el sapo en el cerro Verde, la frontera entre cuicatecos de Teotilalpan y chinantecos de Ojitlán representada en el cerro Mujer y su cueva, la marcada por el cerro Rabón entre la mazateca Baja y Media, la establecida entre chatinos de Zenzontepec y mixtecos de Tututepec mediante el cerro Yucusáa, la delimitada entre tacuates de Santa María Zacatepec y amuzgos de San Pedro Amuzgos mediante la competencia por las campanas, y la pelea entre los naguales de esta misma comunidad tacuate y los amuzgos de Santa María Ipalapa.

Parece importante concluir que identificando centros y fronteras allí donde los santuarios, los mitos y los rituales nos los señalan, podemos trazar mapas de la geografía simbólica de los etnoterritorios. Aun cuando la construcción de la territorialidad es un proceso dinámico que excluye e incluye santuarios y cambia las fronteras, de por sí difusas, los lugares sagrados emblemáticos muestran una gran profundidad temporal y constituyen fenómenos-guía para la delimitación de los espacios culturalmente significativos.

En este trabajo se ha intentado una lectura de los procesos de construcción-apropiación territorial que protagonizan los grupos indígenas de Oaxaca, y llamado etnoterritorios a esas configuraciones históricas y contemporáneas. Por razones metodológicas esos procesos se han investigado a partir de un modelo de representación del espacio que articula las dimensiones vertical y horizontal y las nociones de centro, frontera, umbrales y redes. Este modelo me ha permitido organizar una representación del espacio que he podido aprehender en los grupos trabajados, a partir de las categorías etnográficas escogidas para el análisis (cosmovisión, narrativa y procesos rituales), instrumentos seleccionados en razón 
de que la búsqueda iba encaminada a investigar la etnoterritorialidad sagrada.

De hecho, ha sido la mitología fundacional y la rica narrativa sobre los lugares sagrados, junto con los múltiples rituales realizados en santuarios naturales o construidos, los que me han sugerido los centros, así como los mitos de competencia y de privación han mostrado la delimitación de fronteras de los territorios locales y de los globales o etnoterritorios, y las procesiones y peregrinaciones del mundo del medio y del inframundo han marcado las redes de los etnoterritorios (A. Barabas, 1993C). Si me es dado arriesgar una propuesta, diría que parecen ser las propias categorías indígenas las que permiten establecer centros, fronteras y redes, intersectados por umbrales, no sólo como nociones claves para la representación del espacio sino como lugares de la memoria y del paisaje vivido, pero susceptibles de ser ubicados en un mapa. Ciertos casos, como los ya mencionados, muestran una sugerente correspondencia entre las fronteras etnoterritoriales simbólicas y las lingüístico-culturales.

Multitud de ejemplos en culturas de Oaxaca indican que los indígenas han reconocido los territorios de sus grupos y sus fronteras y vecindades a lo largo de la historia prehispánica y colonial, tal como dejan ver los códices, lienzos, mapas y títulos primordiales. El proceso colonial de fragmentación de señoríos y de recongregación favoreció el encapsulamiento de las identidades étnicas en los niveles comunales, oscureciendo en muchos casos el conocimiento de los indígenas sobre sus antiguos etnoterritorios y facilitando la confusión entre éstos y las tierras comunales o ejidales. No obstante, son numerosos los grupos que tienen memoria de su historia en el lugar, de los límites y colindancias del territorio étnico global, conocimiento no sólo geopolítico sino también simbólico.

\section{Bibliografía}

Albores, Beatríz y Johanna Broda (coords.), 1997, Graniceros. Conmovisión y metereología indígenas en Mesoamérica, El Colegio Mexiquense-UNAM, México.

Altman, Irwin y Martin Chemers, 1980, Culture and Environment, Brooks/Cole, Pubs. Company, California.

Arvelo, Nelly y Keith Conn, 1995, “The Ye'kuana Self-De- marcation Process", en Cultural Survival Quarterly, Estados Unidos.

Avendaño, Encarnación, 2001, Identidad y movimiento agrario en una comunidad triqui, tesis de licenciatura, ENAH.

Aveni, Anthony, 1991, "Mapping the Ritual Landscape: Debt Payment to Tlaloc During the Month of Atlacahualo", en David Carrasco (ed.), To Change Place. Aztec Ceremonial Landscapes, Colorado University Press.

Barabas, Alicia, 1991, "El aparicionismo en América Latina: religión, territorio e identidad”, en A. Pérez Castro (ed.), La identidad: imaginación, recuerdos y olvidos, IIA-UNAM, México.

—_, 1997, "La aparición de la Virgen en Oaxaca, México. Una interpretación sobre la multivocalidad del milagro", Thule. Rivista Italiana di Studi Americanistici, Argo, Perugia, Italia.

__, 1999, "Los ruu ngigua o gente de idioma. El grupo etnolingüístico chocholteco", en A. Barabas y M. Bartolomé (coords.), Configuraciones étnicas en Oaxaca, vol. III, INAH/INI, México.

— 2002, Utopías indias. Movimientos sociorreligiosos en México, Plaza y Valdés-INAH, México.

—_, 2003a, "La ética del don en Oaxaca. Los sistemas indígenas de reciprocidad", en S. Millán y J. Valle (coords.), La comunidad sin limites, vol. I, Conaculta-INAH (col. Etnografía de México, serie Ensayos), México.

_ 2003b, "Procesos rituales", en Atlas etnográfico de Oa$x a c a$, FCE-INAH (en prensa).

__ 2003c, "Etnoterritorialidad sagrada en Oaxaca", en A. Barabas (coord.), Diálogos con el territorio. Simbolizaciones sobre el espacio en las culturas indígenas de México, vol. I, Conaculta-INAH (col. Etnografía de México, serie Ensayos), México.

Barabas, Alicia y Miguel Bartolomé, 1984, El rey Cong Hoy. Tradición mesiánica y privación social entre los mixes de Oaxaca, CRO-INAH, Oaxaca.

— 1993 , Narrativa chontal, Centro INAH Oaxaca (serie Narrativas étnicas, núm. 3), Oaxaca.

—_, 1999, Configuraciones étnicas en Oaxaca. Perspectivas etnográficas para las autonomías, 3 vols., INAH-INI (col. Científica), México.

Bartolomé, Miguel, 1984, El ciclo mítico de los hermanos gemelos Sol y Luna en las tradiciones de las culturas oaxaqueñas, CECOAX-CRO-INAH, Oaxaca.

Bartolomé, Miguel y Alicia Barabas, 1996, La pluralidad en peligro, INAH-INI (col. Regiones de México), México.

— 1996, Tierra de la palabra. Historia y etnografía de los chatinos de Oaxaca, INAH-IOC-FONCA, Oaxaca.

Broda, Johanna y Féliz Báez-Jorge (coords.), 2001, Cosmovisión, ritual e identidad de los pueblos indigenas de México, FCE, México. 
Cardoso de Oliveira, Roberto, 1983, "As categorias do entendimento na formaçao da Antropologia", Anuario Antropológico, núm. 81, Tiempo Brasileiro.

Casey, Edward, 1996, "How to Get From Space to Place in a Fairly Short Stretch of Time: Phenomenological Prolegomena”, en Senses of Place, School of American Research Press, Santa Fe, Nuevo México.

Douglass, William, 1999, "Fronteras: la configuración de los mapas mentales y físicos en el Pirineo", en J. J. Pujadas, E. Martín Díaz y J. Pais de Brito (coords.), Globalización, fronteras culturales y políticas y ciudadanía, VIII Congreso de Antropología, Santiago de Compostela.

Eliade, Mircea, 1967, Lo sagrado y lo profano, Guadarrama, Madrid.

— 2000, Aspectos del mito, Paidós, España.

Ericksen, Gordon, 1980, The Territorial Experience. Human Ecology as Symbolic Interaction, University of Texas Press.

Escalera, Javier, 1999, "Territorio, límites, fronteras: construcción social del espacio e identificación colectiva”, en J. J. Pujadas, E. Martín Díaz y J. Pais de Brito (coords.), Globalización, fronteras culturales y políticas y ciudadanía, VIII Congreso de Antropología, Santiago de Compostela.

Feld, Steven y Keith Basso (eds.), 1996, Senses of Place, School of American Research Press, Santa Fe.

Galinier, Jacques, 1990, La mitad del mundo. Cuerpo y Cosmos en los rituales otomies, UNAM-CENCA-INI, México.

Giménez, Gilberto, 1999, “Territorio, cultura e identidades. La región sociocultural”, Estudios sobre las Culturas Contemporáneas, época II, vol. V, núm. 9, Colima.

__, 2001, "Cultura, territorio y migraciones. Aproximaciones teóricas", Sociedad Mexicana de Antropología, Zacatecas (no publicado).

Glockner, Julio, 1996, Los volcanes sagrados. Mitos y rituales en el Popocatépetl y la Iztacíhuatl, Grijalbo, México.

Gupta, Akhil y James Ferguson, 1992, "Beyond Culture: Space, Identity and the Politics of Difference", Culture Anthropology, vol. 7 , núm. 1.

Hirsch, Eric y Michael O’Hanlon, 1995, "Landscape: Between Place and Space”, en E. Hirsch y M. O’Hanlon (eds.), The Anthropology of Landscape. Perspectives on Place and Space, Clarendon Press, Oxford, Inglaterra.

Incháustegui, Carlos, 2000, "Entorno enemigo. Los mazatecos y sus sobrenaturales", Desacatos. Revista de Antropología Social, núm. 5, CIESAS, México.

Jansen, Maarten, 1998, "La fuerza de los cuatro vientos. Los manuscritos 20 y 21 del Fonds Mexicain", Journal de la Société des Américanistes, núm. 84-2, París.

Jolivet, Marie-José (ed.), 2000, "Logiques identitaires, logiques territoriales", Cahiers des Sciences Humaines, nouvelle série, núm. 14.
Kuroda, Etsuko, 1993, Bajo el Zempoaltépetl. La sociedad mixe de las sierras altas y sus rituales, CIESAS-IOC, Oaxaca.

Leenhardt, Maurice, 1961, Do Kamo, Eudeba, Buenos Aires.

López Austin, Alfredo, 1984, Cuerpo humano e ideología. Las concepciones de los antiguos nahuas, UNAM, México.

-1989 , Hombre Dios. Religión y política en el mundo náhuatl, UNAM, México.

—_, 1990, Los mitos del tlacuache. Caminos de la mitología mexicana, Alianza Editorial Mexicana, México.

Myers, Fred, 1986, “The Dreaming: Time and Space”, en Pintupi Country, Pintupi Self Sentiment, Place and Politics among Western Desert Aborigines, Smithsonian Institution Press, Washington.

Medina, Andrés, 2000, En las cuatro esquinas en el centro. Etnografía de la cosmovisión mesoamericana, IIA-UNAM, México

Otto, Rudolph, 1965, Lo santo, Selecta Revista de Occidente, Madrid.

Prat, Joan, 1989, "Los santuarios marianos en Cataluña”, en C. Álvarez, M. Buxó y S. Rodríguez (eds.), La religiosidad popular, vol. III. "Hermandades, romerías y santuarios”, Anthropos, Barcelona.

Raffestin, Claude, 1989, “Qu'est-ce que le Territoire?”, en Pour une geographie du pouvoir, LITEC, París.

Rodman, Margaret, 1992, "Empowering Place: Multilocality and Multivocality”, American Anthropologist, vol. 94, núm. 3, AAA, Washington.

Schama, Simon, 1995, Landscape and Memory, A. K. Published, Nueva York.

Smith, David, 1990, "Introduction: the Sharing and Dividing of Geographical Space", en M. Chisholm y D. Smith (eds.), Shared Space, Divided Space. Essays on Conflict and Territorial Organization, Unwin Hyman Lt, Londres.

Soja, Edward, 1985, "The Spatiality of Social Life: Towards a Transformative Retheorisation”, en Social Relations and Spatial Structures, St. Martin Press, Nueva York.

Turner, Victor, 1980, La selva de los símbolos, Siglo XXI, México.

Valcuende del Río, José María, 1999, "Espacio, territorio y comunidad: procesos de identificación y discursos", en J. J. Pujadas, E. Martín Díaz y J. Pais de Brito (coords.), Globalización, fronteras culturales y políticas y ciudadanía, VIII Congreso de Antropología, Santiago de Compostela.

Valdés del Toro, Ramón, 1993, "Caminos hacia el centro. Hacia una fenomenología del espacio sagrado", en Romarias e Peregrinacións, Actas do Simposio de Antropología, Conselho da Cultura Galega, Santiago de Compostela.

Weitlaner, Roberto, 1977, Relatos, mitos y leyendas de la Chinantla, INI (serie Antropología Social, col. INI, núm. 53), México. 